\title{
Tephra studies in New Zealand: an historical review
}

\author{
David J. Lowe*
}

The development of tephra studies in New Zealand may be divided into four main periods: Period I, late 19th century to late 1920s; Period 2, late 1920s to early 1950s; Period 3, early 1950s to 1973; Period 4, 1973 to late 1980s. The important events and advances that characterise each of these periods, and their causes and influences, are described with reference to contemporary scientists and their publications. Period 1: determination by dendrochronology of first numerical age of a prehistorical eruptive (Burrell Lapilli); first isopach map (Tarawera Tephra). Period 2: first tephra mapping in central North Island (for soil survey). Period 3: first use of ${ }^{14} \mathrm{C}$ dating; establishment of late Quaternary tephrostratigraphic framework by 'hand-over-hand' mapping in central North Island and Taranaki; initial development of tephra 'fingerprinting' using laboratory methods; application of tephrochronology to many disciplines. Period 4: revision and refinement of proximal stratigraphy, particularly in central TVZ calderas and on Mayor Island; extension of tephra mapping to distal regions, on and offshore, and to older deposits; advances in rephra correlation and dating methods; new tephrochronological applications; revoluticnary studies of pyroclastic deposits for determining nature and effects of eruptions (physical volcanology and petrology); renewed awareness of volcanic hazards associated with tephra eruptions. The advances relate to indigenous, external, and 'individualistic' factors. They generally parallelled overseas trends but in some topics preceded or lagged behind them. Tephra studies, or "tephrology", may be regarded as having "come of age" early in the 1980s, about 100 years after the first tephrostratigraphic studies in New Zealand.

Keyu'ords: tephostratigraphy, tephrochronology, volcanic ash, pyroclastic deposits, volcanology, history of science

\section{INTRODUCTION}

Current plate tectonic models show that the North Island of New Zealand lies on the leading edge of the Australian Plate and is being obliquely underthrust by the subducting oceanic Pacific Plate (Cole, 1986; Kamp, 1986). Volcanic activity resulting from the interaction of these lithospheric plates has been a feature of the geological development of much of the central North Island in the Quaternary, and large quantities of lava and pyroclastic material, mainly of rhyolitic and andesitic composition, have been erupted from volcanoes in the Taupo Volcanic Zcne (TVZ), and from Mt Egmont and Mayor Island (Fig. 1; Cole and Nairn, 1975; Healy, 1982; Wilson et al., 1984; Smith, 1986).

These eruptive deposits, especially the lavas, have been the subject of study for around 100 years (e.g. see Suggate et al., 1978), but it is only in the past 50 years or so that the pyroclastic deposits have received any detailed attention. Of particular interest are the unconsolidated pyroclastic or tephra deposits, which are widespread and form a more or less continuous mantle over about $20 \%$ of the relatively small land mass of North Island (Pullar et al., 1973; McCraw, 1975). The development of the study of these tephra deposits, chiefly those of airfall origin, and their application as a dynamic research tool in the earth sciences, is the principal subject of this historical review. In particular, I attempt to highlight the more important advances that have been made in tephra studies in New Zealand and who made them, and to show how they relate to certain events or to technological advances in New

* Department of Earth Sciences, University of Waikato, Private Bag 3105. Hamilton, New Zealand 


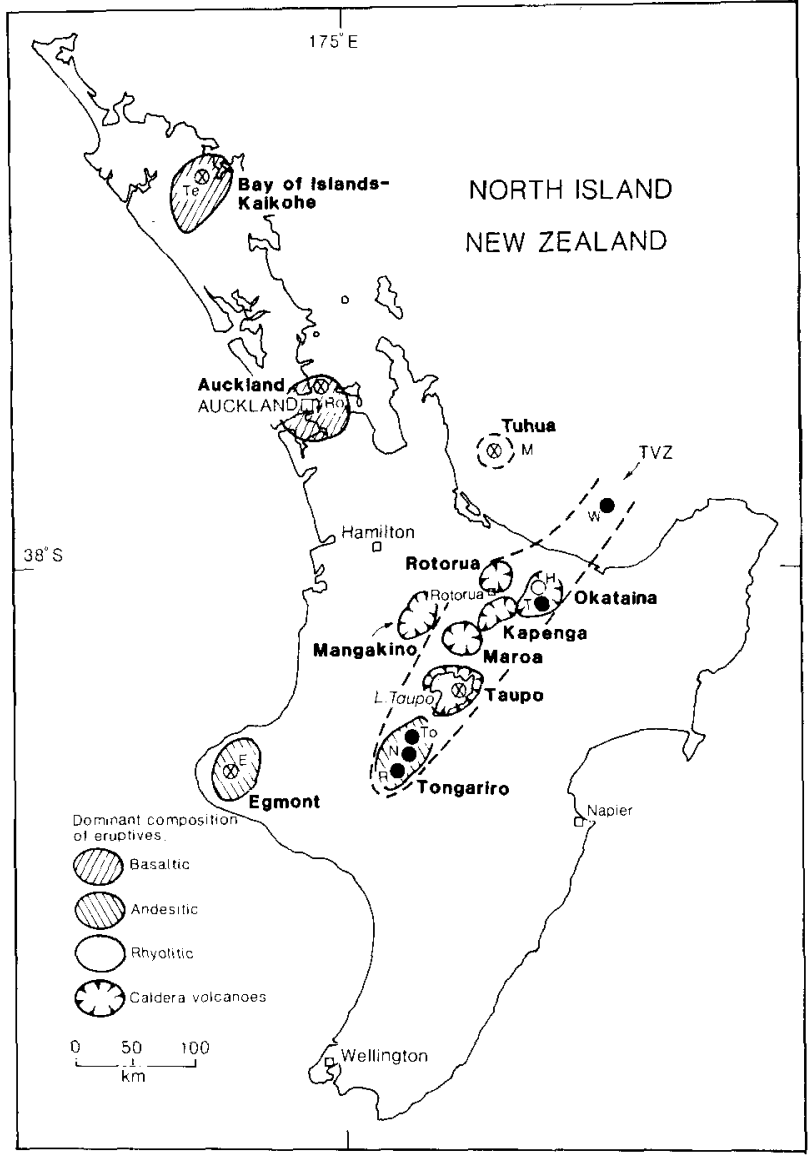

Fig. 1 - Distribution of volcanic centres or districts (bold names) in the North Island active in the last $c .0 .5$ million years. TVZ, Taupo Volcanic Zone (dashed); closed circles, volcanoes that have erupted since (., $1850 \mathrm{AD}$. (recorded history); crosses, volcanoes that have erupted during the last $c .1800$ years (dated mainly by ${ }^{14} \mathrm{C}$ or dendrochronology; note that the most recent eruption from Mt Egmont may have been less than 200 years ago: Neall and Alloway, 1986; Neall et al., 1988); open circles, volcanoes that have erupted during the last $c .5000$ years (dated by ${ }^{1+} \mathrm{C}$ ). Named volcanoes are: $\mathrm{M}$, Mayor Island; W, White Island; H. Haroharo; T, Mt Tarawera; To, Mt Tongariro: N, Ngauruhoe; R, Mt Ruapehu; E, Mt Egmont (also known as Mt Taranaki); Ro, Rangitoto Island; Te, Te Puke (after Cole and Nairn, 1975; McCraw, 1975; Buck et al., 1981; Wilson et al., 1984; Froggatt and Lowe, 1990). N.B.: Wilson et al. (1986) postulated the existence of 'Whakamaru caldera' (in the northern Taupo-Maroa area) in addition to those shown here. overseas.

The review is complementary to that of Froggatt and Lowe (1990) in which the nomenclature, stratigraphy, distribution, volume, and age of late Quaternary silicic tephra formations in New Zealand are described and discussed in detail.

\section{DEVELOPMENT OF TEPHRA STUDIES IN NEW ZEALAND}

The development of tephra studies and the establishment of tephrostratigraphy and tephrochronology (a method of dating past geological events and landscapes based on the identification, correlation, and dating of airfall tephra layers) as a separate discipline in New Zealand may be traced through four broad periods:

Period 1 : late 19 th century to late $1920 \mathrm{~s}$

Period 2 : late 1920 s to early $1950 \mathrm{~s}$

Period 3 : early 1950 s to 1973

Period 4 : 1973 to late 1980 s

Some of the people and significant events in the history of tephra studies in each of these periods, and their influences, are described below.

\section{Period 1 (late 19th century to late 1920s)}

European geologists undertook reconnaissance and regional mapping, chiefly of hard rocks, but also noted the widespread pyroclastic materials and commented on possible stratigraphic relationships. In the Taupo district, von Hochstetter (1864, translated by Fleming) described some of the pyroclastic deposits as "volcanic fragmental rocks" of rhyolitic composition (p.116). Later writers (e.g. Crawford. 1876; Smith, 1877; Cussen, 1888; Hill, 1888; McKay, 1899) described the pumice deposits around Lake Taupo and elsewhere in more detail. Cussen (1888, p. 327) noted that "as we recede from Taupo the [Taupo] pumice deposit thins out gradually, and the particles decrease in size, until at a distance of 50 miles $[80 \mathrm{~km}]$ from the centre of the lake very little is seen, and that in very small particles." Based 


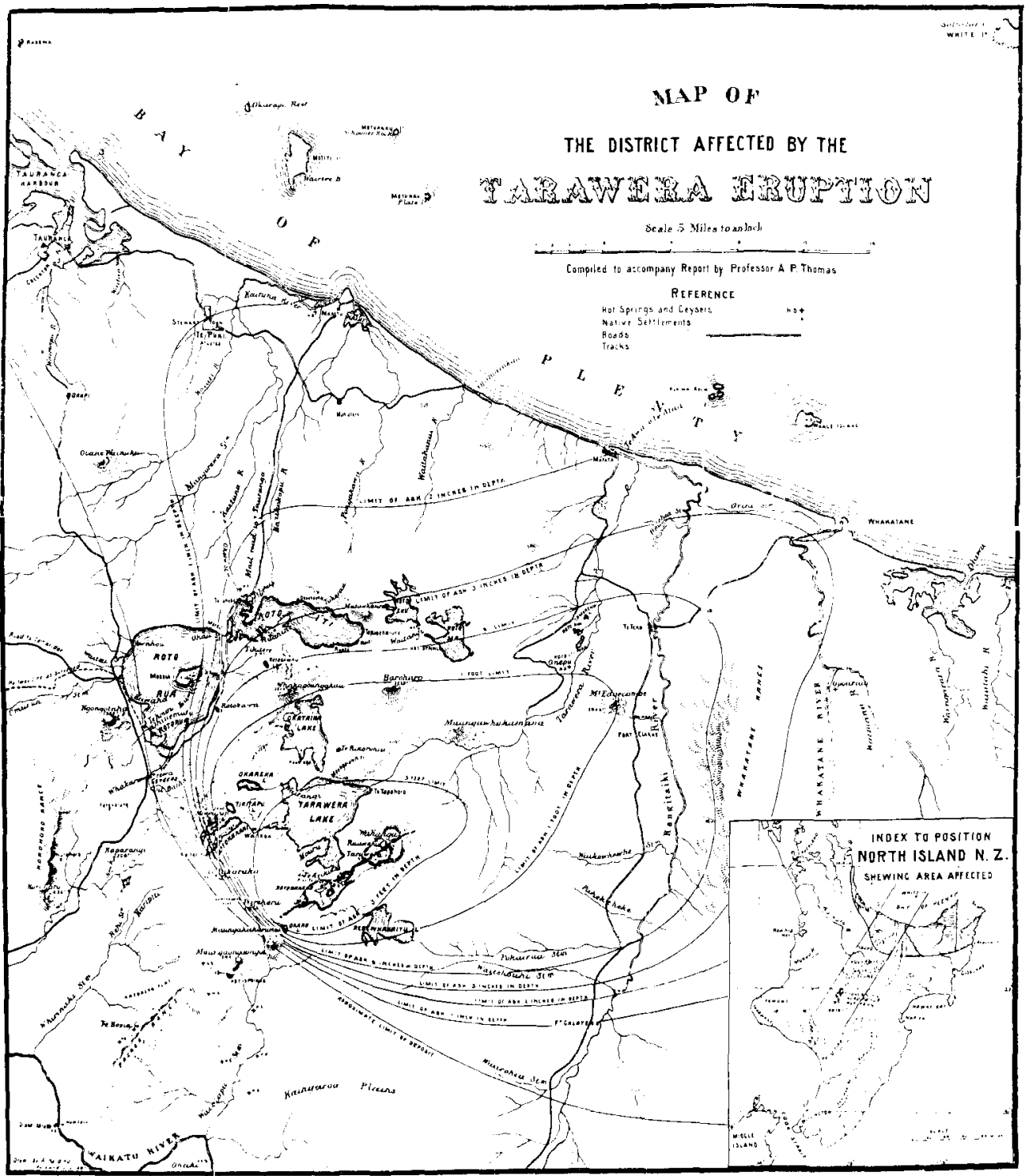

Fig. 2 - Isopach map of tephra fallout from the Tarawera eruption of 10 June, 1886, as determined by Thomas (1888, map I) (c.f. maps of Pullar and Birrell, 1973b; Walker et al., 1984). N.B.: I ft $=0.305 \mathrm{~m}$.

on the great extent and topographic distribution of the pumice, Cussen concluded (p. 328) that "all the evidence so far goes to show that it was spread in the air, and, I think, points to the region of Lake Taupo as the centre of distribution", with the pumice particles "being carried by the violent tornado of escaping gases high up into the air, and for miles in any direction that the prevailing wind may take them".

Subsequently, A.. P. W. Thomas (1889) used mineralogy and whole rock chemical analyses (p. 349) of Taupo Pumice, together with thickness relationships, to demonstrate that it was not derived from Tongariro volcano as several earlier writers (e.g. Smith, 1877) had suggested (Mt Tauhara was suggested as a possible source instead). He also described andesitic ash beds and paleosols formed within them on Mt Tongariro. 
The eruption of Mt Tarawera in 1886 resulted in the publication of the first isopach map in New Zealand (Fig. 2; Thomas, 1888), and stimulated awareness that other volcanoes may have spread showers of ash to distal parts of the North Island in the recent past. For example, Hill (1887) analysed soil samples from eastern North Island and reached the following interesting conclusions (pp. 386-7):

"From the results of my experiments I feel convinced that the East Coast District of this island has been subject, at a not very remote date, to dust showers of volcanic ejectamenta. Had the wind been blowing from the north-west at the time of the recent eruptions, it is a matter of certainty that the dust showers which fell in the district extending in a north-easterly direction for about 120 miles from the seat of the volcanic outburst, would have fallen throughout the East Coast District as far as Napier and the Hawke's Bay river system. Within 75 miles of Napier there are many volcanic cones, including the semi-dormant Tongariro and the not-altogether-extinct cone of Ruapehu - the highest point of elevation in the North Island; and although this district is separated by the Ruahine chain of mountains, and other minor ranges, from what may be termed the zone of active volcanic phenomena, as represented by hot springs, solfataras, geysers, and burning mountains, it is certainly not outside the zone of volcanic influences, the effects of which may be seen at any time along the East Coast. A recurrence of activity in and about the district of which Lake Taupo is the natural centre, would undoubtedly bring showers of volcanic dust and debris as far as Napier, should the wind be blowing in this direction at the time; but I cannot agree with those who say that such showers would be detrimental to vegetation. They may cause temporary inconvenience, but of their beneficial effects in the production and formation of soils I think there can be no question for a doubt. To me, volcanic dust showers are blessings in disguise. They may cause loss and inconvenience at the time of their deposition; but they contain within their particles the elements of fertility, and only need, like wine, age to make them valuable adjuncts in the formation of rich soils."

The first numerical age attached to a prehistoric tephra deposit appears to have been determined in the Taranaki district in 1883 by A. W. Burrell (Oliver, 1931; Druce, 1966). Burrell used tree-ring counts from a matai tree (Podocarpus spicatus), in the forks of which "scoria" (lapilli) were lodged, to obtain an eruption age of $c .1430$ AD for the Burrell tephra (the most recent estimate for the age of the Burrell Formation is c. 1655 AD: Druce, 1966). Oliver's (1931) report on the age of burial of a Maori oven (umu) by the tree-ring dated Burrell Formation may qualify as the first application of tephrochronology (using a prehistoric tephra) in New Zealand.

The eruption of Mount Pelée in 1902 and the ensuing destruction of the town of St Pierre on Martinique in the West Indies awakened memories of the Tarawera eruption and resulted in the visit of an American volcanologist, T. A. Jaggar, to New Zealand in 1910. His ensuing recommendation (Jaggar, 1920), to set up a major volcanological observatory in the central volcanic region, has not yet been fully realised (see Houghton et al., 1988), but eventually it prompted the initiation of detailed geological mapping in the Rotorua-Taupo area by L. I. Grange in 1926 (published in Grange, 1937: see comments pp. 129-130). At around the same time, B. C. Aston surveyed the soils of the Rotorua area and published, using a newlydeveloped classification system based on texture (particle size), the first detailed soil maps in New Zealand (Aston, 1926, 1927). Aston was investigating the serious problem of "bush sickness" (later traced to cobalt deficiency, either inherited from the Taupo Pumice or Kaharoa Tephra deposits, or the result of intense leaching under high rainfall) that became markedly evident during Government farm rehabilitation settlement programmes after World War I. Grange (1929), following Aston's lead, mapped soil-forming ash showers and soils in the Rotorua district and identified the relationship between ash showers, soil series, and bush sickness. 
Status of tephra studies by the end of Period 1

The first steps towards the development of modern tephrostratigraphy and tephrochronology began in Period 1 as the result of a combination of events: the decision to do more detailed geological mapping in the Rotorua-Taupo district, partly because of perceived volcanological and associated hazards; advances in soil classification and soil mapping procedures in New Zealand; and, perhaps most importantly, the urgent need to remedy or mitigate the problem of bush sickness.

\section{Period 2 (late 1920s to early 1950s)}

The recognition of a relationship between the incidence of bush sickness and soil derived from tephra led to extended soil surveys using modern techniques in central North Island, initially by Grange and N. H. Taylor (Grange, 1931; Grange and Taylor, 1932; Grange et al., 1939; Taylor, 1930, 1933, 1953; N.Z. Soil Bureau, 1954). These were carried out as part of the 'Reconnaissance Soil Survey of the Central North Island Territory', which was instituted by the New Zealand Department of Scientific and Industrial Research in collaboration with the Cawthron Institute Trust Board in 1930, and directed by T. Rigg (Grange and Taylor, 1932). During the course of this work, many soil-forming tephra deposits were named, described, and mapped. In these maps (e.g. Fig. 3), the identification of deposits was extended only to about 10-15 cm [4-6 in] (Grange, 1931), chiefly because this was the depth of rooting of grass. (The production of grass dominated agricultural thinking at this time; $J$. D. McCraw, pers. comm., 1989.) Grange and Taylor noted that the ash showers (airfall

Table 1 - Ferromagnesian mineralogy* $(\%)$ of tephra beds at three sites in the Mairoa district (after Taylor, 1933, p. 201). Bed 1 is a composite of tephra deposits from more than one volcano; Bed 2 is probably Kawakawa Tephra.

\begin{tabular}{|c|c|c|c|c|}
\hline & $\begin{array}{r}\text { Depth of } \\
\text { sample } \\
(\mathrm{cm})\end{array}$ & $\mathrm{Hbl}$ & Нyp & Aug \\
\hline \multicolumn{5}{|c|}{ Mairoa } \\
\hline \multirow[t]{4}{*}{ Bed 1} & 8 & 35 & 25 & 40 \\
\hline & 15 & 34 & 26 & 40 \\
\hline & 33 & 30 & 32 & 38 \\
\hline & 56 & 30 & 47 & 23 \\
\hline Bed 2 & 74 & 14 & 73 & 13 \\
\hline \multicolumn{5}{|c|}{ Eight km north of Mairoa } \\
\hline \multirow[t]{4}{*}{ Bed 1} & 8 & - & - & - \\
\hline & 15 & 30 & 22 & 48 \\
\hline & 33 & - & - & - \\
\hline & 56 & - & - & - \\
\hline Bed 2 & 74 & 10 & 75 & 15 \\
\hline \multicolumn{5}{|c|}{ Twenty four km east of Mairoa } \\
\hline \multirow[t]{4}{*}{ Bed 1} & 5 & 37 & 30 & 33 \\
\hline & 23 & 28 & 47 & 25 \\
\hline & - & - & - & - \\
\hline & 61 & 30 & 60 & 10 \\
\hline Bed 2 & 86 & 8 & 77 & 15 \\
\hline
\end{tabular}

* Hbl, calcic hornblende; Hyp, hypersthene; Aug, augite; - = not determined 


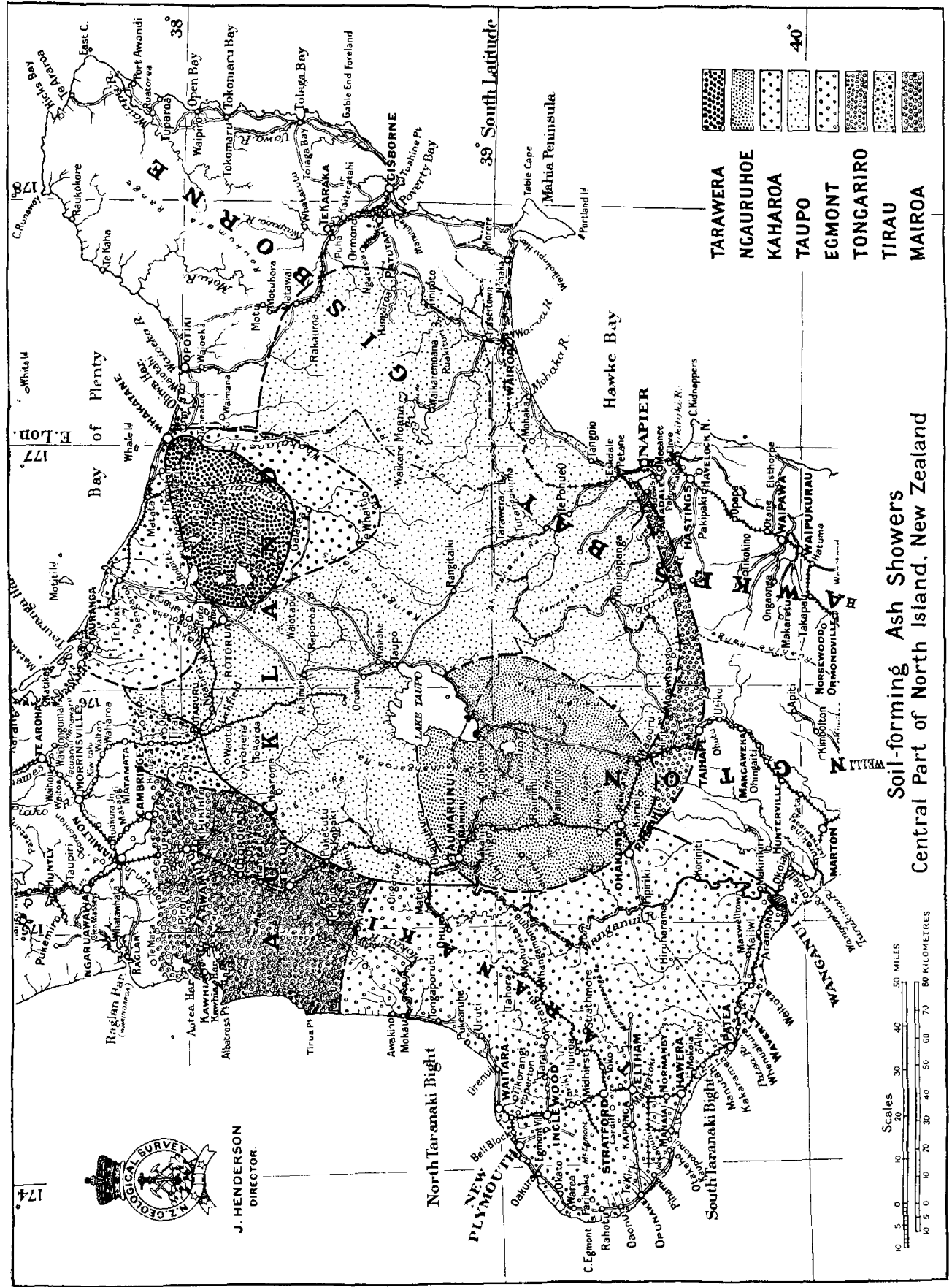

Fig. 3 - Map of soil-forming ash showers in central North Island, New Zealand, based on early soil surveys. Thicknesses of each "shower" are generally c. $15 \mathrm{~cm}[6$ inches] or more (from Grange and Taylor, 1932, facing p. 62). 
tephra) mantle the topography, may exhibit shower bedding, and tend to thin away from source. From mineralogical studies, typically based on samples separated and examined in the field, they recognised contributions from four volcanic areas: Taupo, Rotorua, Tongariro, and Egmont (Table 1). Rhyolitic tephras were generally attributed to paroxysmal, and andesitic tephras to intermittent, eruptions (Taylor, 1933).

Although exotic timber trees were first planted in the central volcanic region in 1898 , plantings by both state and private interests boomed in the 1926-1936 period, particularly with the availabilty of cheap land and labour during the financial depression (MOW, 1962). Pinus radiata was found to be the most suitable timber species. This afforestation was to have an indirect intluence on the rate of development of tephra studies when large stands began maturing in the $1950 \mathrm{~s}$.

\section{Status of tephra studies by the end of Period 2}

This period thus marks the beginning of tephra mapping in New Zealand, and might be described as one of 'proto-tephrostratigraphy'. The work was initially undertaken to provide a better understanding of soils and their parent materials, and many subsequent advances in tephrostratigraphy in New Zealand, particularly in Period 3, were made by pedologists (McCraw, 1975).

Studies of tephra layers as a tool for research in various disciplines (i.e. the development of tephrochronology) began in Iceland and other countries around 1930 (see Thorarinsson, 1981; Sigurdur Thorarinsson, an Icelandic volcanologist, is widely regarded as the "father of tephrochronology'). In a remarkable paper mainly describing the nature and origin of chalazoidites (accretionary lapilli) on Scinde Island, Napier, Berry (1928) also made the following perceptive comments about the future role of tephrochronology in New Zealand (p.608; italics added):

"It seems that a study of volcanic [ash] layers will acquire more importance as knowledge of them increases. In an eruption, for example, in Miocene times, where volcanic material had covered a widespread area of country, it seems extremely probable that much valuable information would be obtained as to the contemporaneity of various deposits, and what effect influences such as climate, depth of water, etc., have had in altering the fauna and flora, if this particular volcanic deposit could be identified by its continuity and its physical and chemical peculiarities."

\section{Period 3 (early 1950s to 1973)}

\section{Radiocarbon datins}

The advent of radiocarbon dating and the establishment of the first radiocarbon dating laboratory in New Zealand in the early 1950 s at Lower Hutt provided the means for obtaining a numerical chronology of tephra eruptions of late Quaternary age. The first ${ }^{14} \mathrm{C}$ date published in New Zealand (NZ1 1,820 150 years BP) was on carbonised wood from within the Hatepe Lapilli (Fergusson and Rafter, 1953).

A paper published by I. L. Baumgart (1954) is a benchmark study for the early part of this period because it was the first to focus on the stratigraphy and chronology (based on ${ }^{14} \mathrm{C}$ dating) of a sequence of tephras erupted from a single source. Baumgart (1954) and Baumgart and Healy (1956) used the tephrostratigraphic record to interpret the recent volcanological history of the Taupo volcano. In addition, they also published the first isopach maps for Taupo Lapilli, Rotongaio Ash, Hatepe Lapilli (members of Taupo Pumice Formation: Froggatt, 1981a), and Waimihia Lapilli (Fig. 4), from which the locations of possible source vents were inferred.

\section{Regional tephrostratigraphy and tephrochronology}

The framework for a regional stratigraphy of late Quaternary tephras in the central North Island developed from this point, aided considerably by the exposure of many new cuttings 


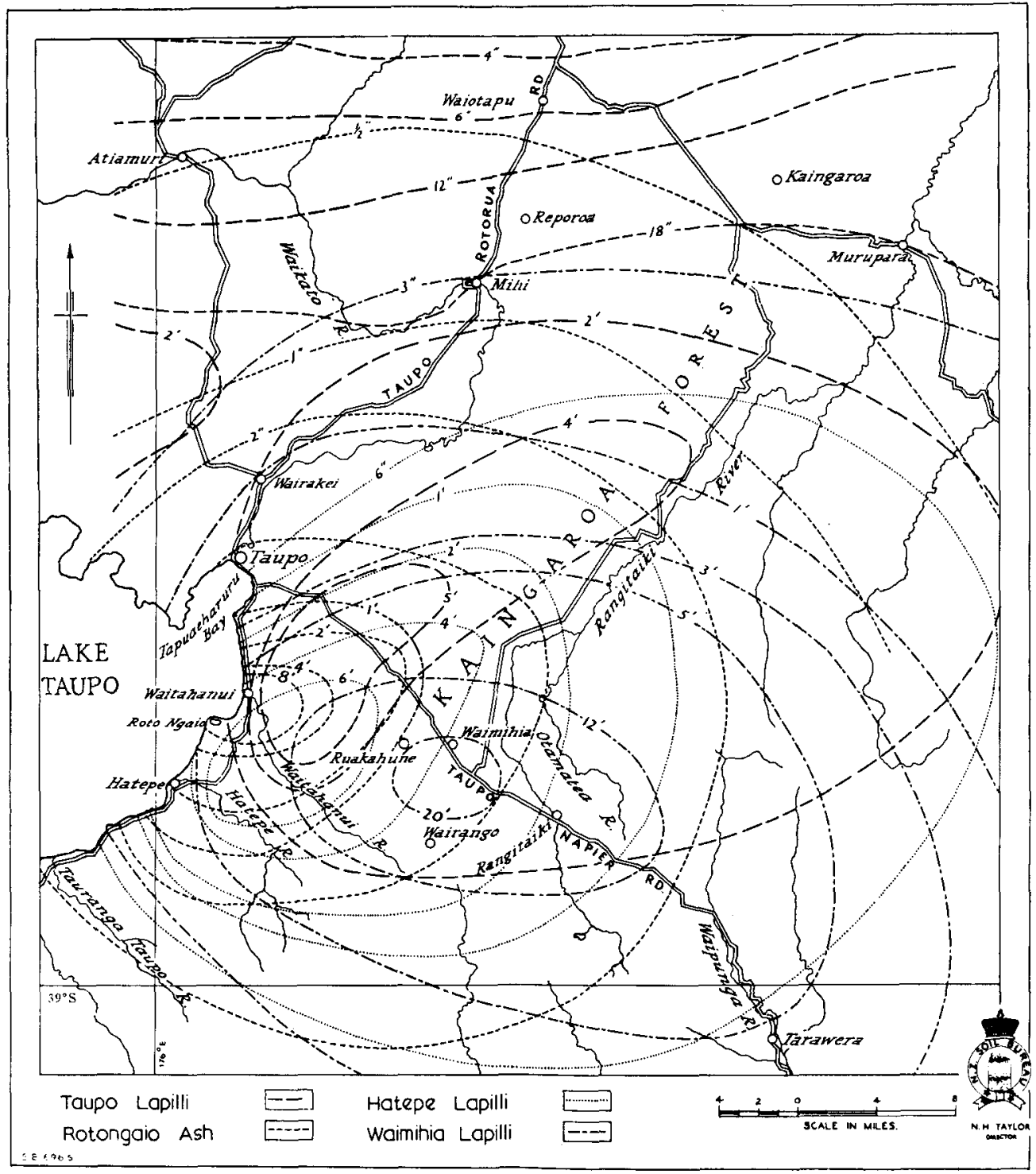

Fig. 4 - Isopachs of some ${ }^{14} \mathrm{C}$-dated tephra deposits erupted from the Taupo Volcanic Centre (from Baumgart, 1954, facing p. 461).

during the course of road construction, especially for access to the maturing exotic forests that had been planted in the 1920s-1930s. Two scientists, C. G. Vucetich and W. A. Pullar (Fig. 5), were outstanding leaders in this endeavour, and ahead of contemporary scientists overseas. Their achievements are even more notable when it is realised that much of their tephra mapping was undertaken in their own time as "secret correlation missions" peripheral to their main duties and against Soil Bureau, DSIR, policy (Vucetich, 1977; C. G. Vucetich, pers. comm., 1983). Vucetich $(1977,1983)$ acknowledged the support of Professor H. W. Wellman in particular to maintain the tephra work, and the contribution made by K. S. Birrell with associated laboratory analyses.

J. Healy, a volcanologist with the New Zealand Geological Survey, also made a significant contribution with his study of the Holocene tephra deposits of the Taupo area (Healy, 1964). 
His work, although carried out independently, was published jointly with that of Vucetich and Pullar (1964) in N.Z. Geological Survey Bulletin 73. Together, these three authors placed tephrostratigraphy on a sound scientific footing and, with the highly-regarded companion paper of Vucetich and Pullar (1969), set the pattern for tephra studies in New Zealand.

Tephra deposits were correlated by detailed 'hand-over-hand' methods that traced deposits from cutting to cutting using the physical properties of the tephras and associated paleosols, marker beds, and the principles of stratigraphy (e.g. Healy, 1964; Vucetich and Pullar, 1963, 1964, 1969, 1973; Pullar, 1967a; Pullar and McLean, 1966; Tonkin, 1970; Nairn, 1972; Pullar and Nairn, 1972; Kohn and Neall, 1973; Pullar and Birrell, 1973a, b; Topping and Kohn, 1973). New radiocarbon ages were also obtained where possible (Pullar and Heine, 1971), and an improved chronology of eruption history began to emerge.

These studies established stratigraphic procedures and nomenclature, and made wide use of isopach maps and 'picket fence' correlation diagrams to document tephra distribution and thickness patterns, tephrostratigraphic relationships, and to estimate volumes of tephra erupted (based on Cole and Stephenson, 1972). The outermost margins of isopach maps were generally restricted to about $10-20 \mathrm{~cm}$, the minimum thickness for tephra identification based largely on field procedures.

Mapping in areas outside the central TVZ was also undertaken, including Taranaki (Druce, 1966; Neall, 1972; Topping, 1972), Tongariro (Topping, 1973; Topping and Kohn, 1973), and eastern Bay of Plenty (Duncan, 1970). V. E. Neall's (1972) paper represents a major advance towards working out the complex tephrostratigraphy of the Taranaki region.

Some of the older tephra deposits were described (e.g. Te Punga, 1963; Ward, 1967; Ninkovich, 1968; Tonkin, 1970). W. T. Ward's (1967) work on the strongly-weathered Hamilton and Kauroa tephra beds was the first detailed study on older (pre-Rotoehu Ash) deposits, and has been little modified since.

Tephrochronological applications were made in a wide range of earth sciences and related disciplines, including geomorphology (Pullar,
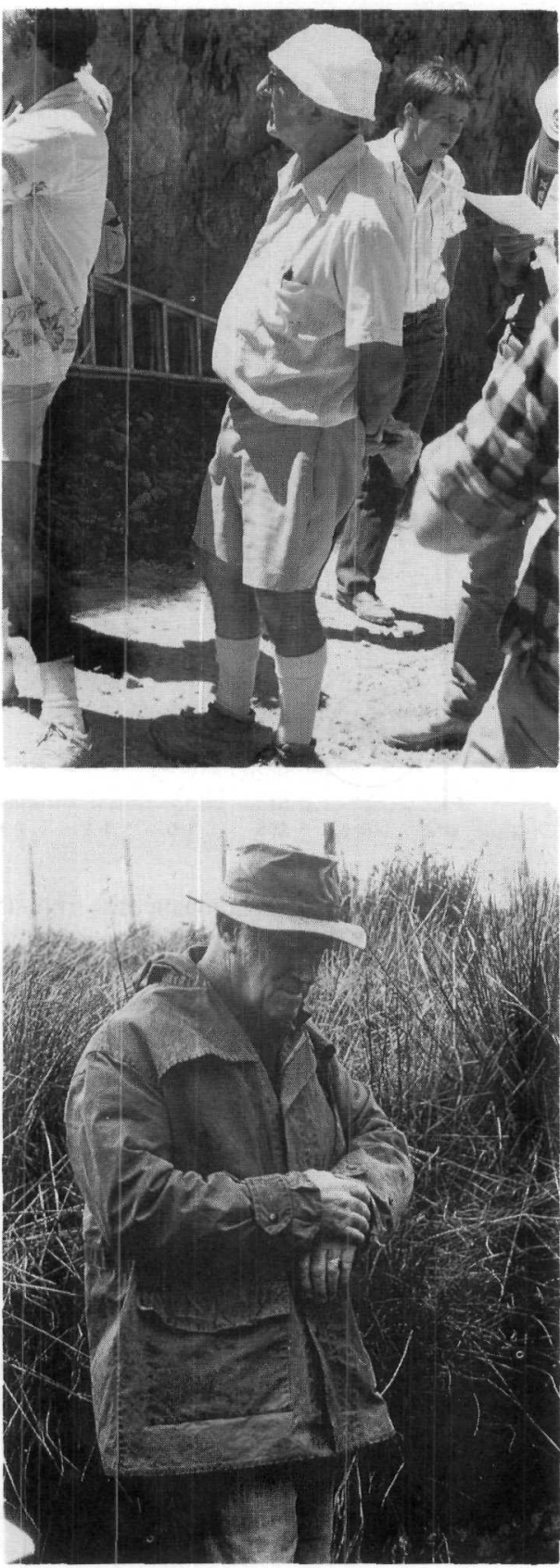

Fig. 5 - (upper) C. G. Vucetich (wearing hat), on a field trip for the International Symposium on Loess, New Zealand (February, 1987): (lower) W. A. Pullar, on a field trip for the Waikato-Bay of Plenty branch of the Geological Society of New Zealand (April, 1978). Photos: D. J. Lowe 1967b, 1973; Pullar and McLean, 1966; Pain and Pullar, 1968; Selby et al., 1971; Milne, 1973), 


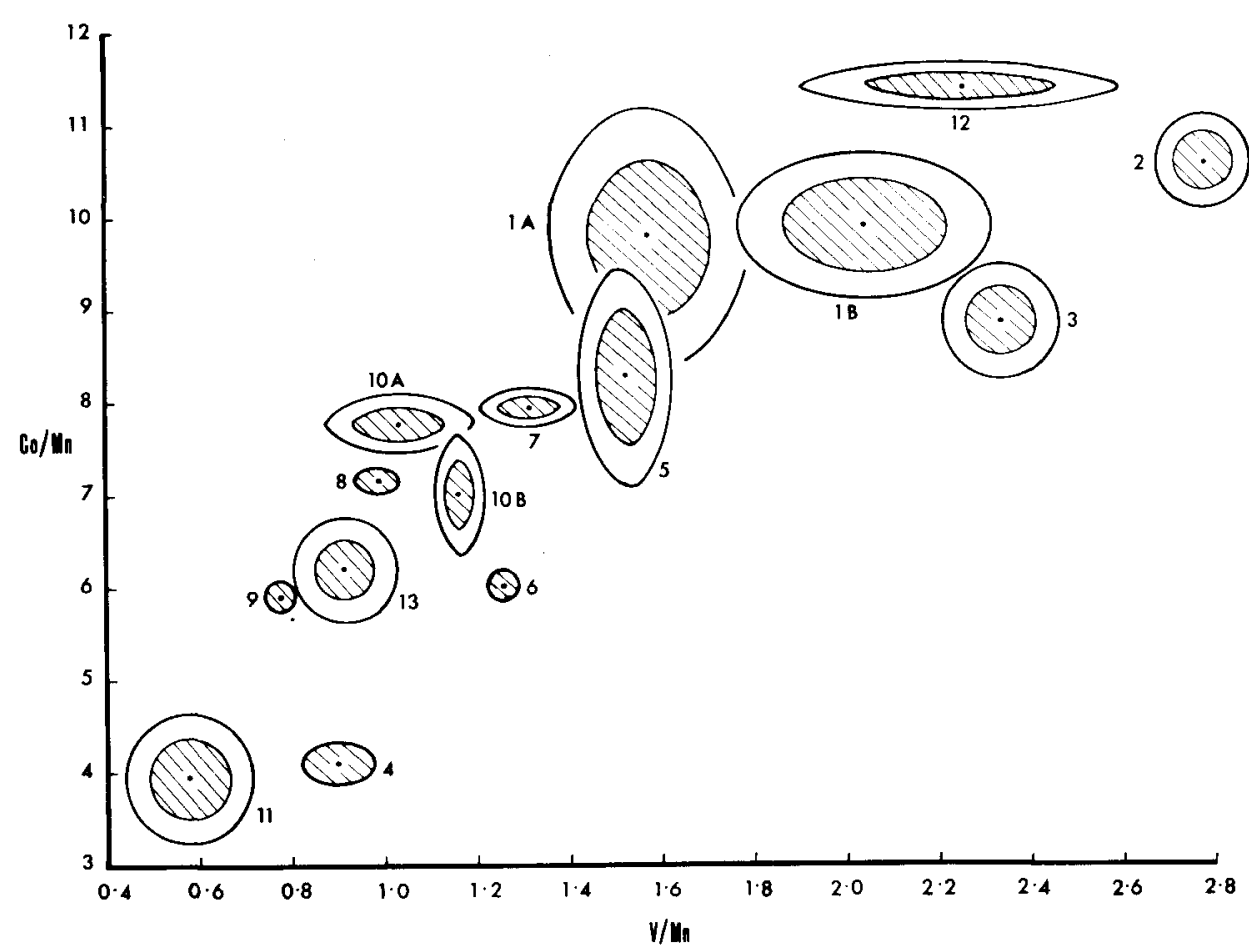

Fig. $6-X^{\prime}$ values of titanomagnetites from 15 New Zealand tephra deposits showing $\mathrm{Co} / \mathrm{Mn}$ ratios plotted against $\mathrm{V} / \mathrm{Mn}$ ratios (based on analysis of bulk samples). $\mathrm{X}^{\prime}$ is the antilog of an $\mathrm{X}$ ratio. The mean value for each tephra is represented by a dot; the shaded area includes $68 \%$ (1 std. dev.) of its plotted points; the outer line includes $90 \%(1.645 \mathrm{std}$. dev.) of its plotted points. Only two samples represent tephra $4,6,8$, and 9 , and for these the shaded areas give the mean deviation rather than the the $68 \%$ value (from Kohn, 1970, p. 365). Tephra deposits: 1, Kaharoa (A, northern, B, south-eastern lobe); 2, Taupo Lapilli; 3, Waimihia; 4, Rotokawau; 5, Whakatane; 6, Mamaku; 7, Rotoma; 8, Waiohau; 9 , Rotorua; 10, Rerewhakaaitu (A, phenocryst-rich, B, phenocryst-poor); 11, Oruanui; 12, Mangaone; 13, Rotoehu.

archaeology (Brothers and Golson, 1959; Pullar, 1970), sea level and coastal studies (Wellman, 1962; Pullar and Warren, 1968; Pullar and Penhale, 1970; Pullar and Selby, 1971), loess stratigraphy (Cowie, 1964; Rhea, 1968), and pedology and tephra weathering studies (Birrell and Fieldes, 1952, 1968; Gibbs, 1968; Vucetich, 1968; Birrell and Pullar, 1973) (see also bibliographies in Kohn, 1973; Westgate and Gold, 1974; McCraw, 1975).

\section{Tephra fingerprinting}

Although mineralogical and chemical studies on tephras were comparatively sparse during this period (e.g. Ewart, 1963, 1966, 1971; Cole, 1970; Duncan and Taylor, 1968), they were to lead to the development of laboratory-based tephra 'fingerprinting' methods, particularly as new analytical techniques (including radiometric dating methods) became available in the late 1960 s and 1970 s.

The association of groups of ferromagnesian silicate mineral assemblages with particular eruptives or eruptive centres was first tested by A. Ewart (Ewart, 1963, 1968, 1971) in the course of petrological studies, and subsequently developed by B. P. Kohn to become a tool for aiding tephra identification (Kohn, 1973; Lewis and Kohn, 1973; Kohn and Neall, 1973; Topping and Kohn, 1973; see also Table 3 below). Another important contribution by Kohn was his novel use of the trace element chemistry of bulk Fe-Ti oxides (titanomagnetite) to 


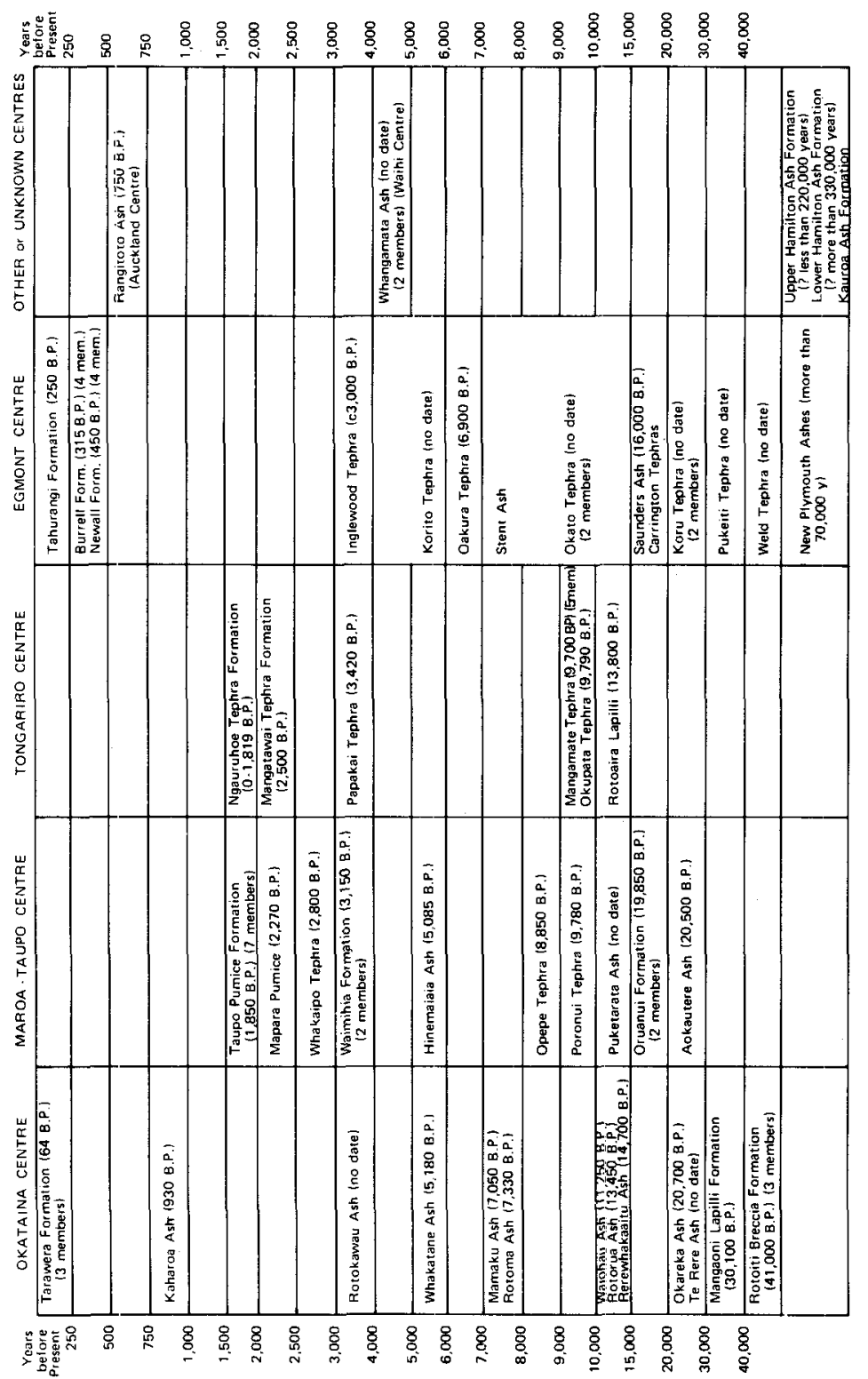

Table 2 - Summary of named tephra formations and published radiocarbon ages from North Island volcanic centres, as known at the end of Period 3 (from McCraw, 1975, p. 38). (c.f. Fig. 10)

characterise and distinguish a range of late Quaternary tephras (e.g. Fig. 6; Kohn, 1970, 1973; Kohn and Neall, 1973). Rankin (1973) attempted tephra correlations using microelement concentrations in bulk glass separates.

INQUA 1973

Period 3 effectively culminated in the 9th International Union for Quaternary Research (INQUA) Congress held in Christchurch, New Zealand, in 1973. A number of papers dealing with tephrostratigraphy and tephrochronology (most have been referred to above) were published in a special issue of the New Zealand Journal of Geology and Geophysics (Volume 
16, Issue 3), and in the Royal Society of New Zealand Bulletin 13 "Quaternary Studies" (published in 1975). Valuable maps and summary papers were given by Pullar and Birrell (1973b), Pullar et al. (1973), and McCraw (1975), and reflect the exciting advances made in the two decades since the early 1950s (Table 2).

\section{Status of tephra studies by the end of Period 3}

The advances of this period can be regarded as an outstanding achievement. A generally sound and immensely useful framework of late Quaternary tephrostratigraphy and tephra distribution had been established for central North Island volcanoes in particular, and wide applications of tephrochronology were being made. At the same time, laboratory methods to help correlate tephras over wide distances were beginning to be developed and applied. The dossier of ages of tephra eruptions was growing, but material suitable for radiocarbon dating was often hard to find.

\section{Period 4 (1973 to late 1980s)}

As in the early 1950s, the early part of this period saw a shift in research emphasis (by Soil Bureau scientists especially) away from the regolith studies so effectively documented at INQUA. A new generation of university graduate students began building on the advances made in Period 3. More specific studies, commonly involving laboratory work to facilitate tephra correlations, were aimed at revising or refining the tephrostratigraphy associated with particular volcanic centres. Studies on distal tephra deposits in a variety of environments became increasingly important. Advances in tephra correlation techniques and physical volcanology proved to be markedly influenced by increasing contact with overseas specialists.

\section{Tephra stratigraphy, chronology, and distribution}

Initially, mapping generally concentrated on revisions of the stratigraphy and distribution of tephra deposits relatively near their sources, namely Okataina (Howorth, 1975; Nairn, 1981), Taupo (Vucetich and Howorth, 1976a, b; Froggatt, 1979, 1981a, b, c; Self, 1983; Froggatt and Solloway, 1986), Tuhua [Mayor Island] (Buck et al., 1981; Houghton et al., 1985; Houghton and Wilson, 1986), and Egmont (Geddes and Neall, 1982; Franks, 1984) volcanic centres.

More distal deposits in the North Island were reported or mapped for Auckland and Northland (Lowe, 1987), Coromandel and western Bay of Plenty (Birrell et al., 1977; Hogg and McCraw, 1983), Waikato (Lowe et al., 1980; Green and Lowe, 1985; Lowe, 1988a), eastern Bay of Plenty, Gisborne and Hawkes Bay (Howorth et al., 1980; Howorth and Ross, 1981; Kohn et al., 1981; McGlone et al., 1984; Lowe and Hogg, 1986), western Taupo (Howorth and Topping, 1979), Taranaki (Stewart et al., 1977; Geddes et al., 1981; Neall and Geddes, 1981; Neall and Alloway, 1986; Alloway et al., 1988; Neall et al., 1988), and the Manawatu, Wanganui, and Wairarapa regions (Milne and Smalley, 1979; Palmer, 1982; Pillans, 1988). Papers by Pullar et al. (1977) and Lowe (1986a, 1988b) cover wider areas of the North Island.

In the South Island, studies on loess and other terrestrial deposits revealed the presence of a number of tephra layers, the best known of which is the c. 22,000 year BP Kawakawa Tephra Formation (Campbell, 1979, 1986; Kohn, 1979; Robertson and Mew, 1982; Mew et al., 1986; Eden, 1987; Eden and Froggatt, 1988; McIntosh et al., 1988).

Role of organic sediments in tephrostratigraphy. Some of the papers noted above showed how useful organic sediments could be in recording tephra deposits in distal localities where the tephrostratigraphy of subaerial exposures is often equivocal, and in establishing the stratigraphic relationships of tephra deposits from different sources $(e . g$. Lowe 1986a, 1988a). Isopach maps in Lowe (1988a) record an outermost thickness of only a few millimetres, a 10 100 times improvement in resolution over many previous maps.

Organic lake sediments and peat deposits additionally provided the opportunity for substantially improving the ${ }^{14} \mathrm{C}$-based chronology of late Quaternary tephra deposits (Lowe 

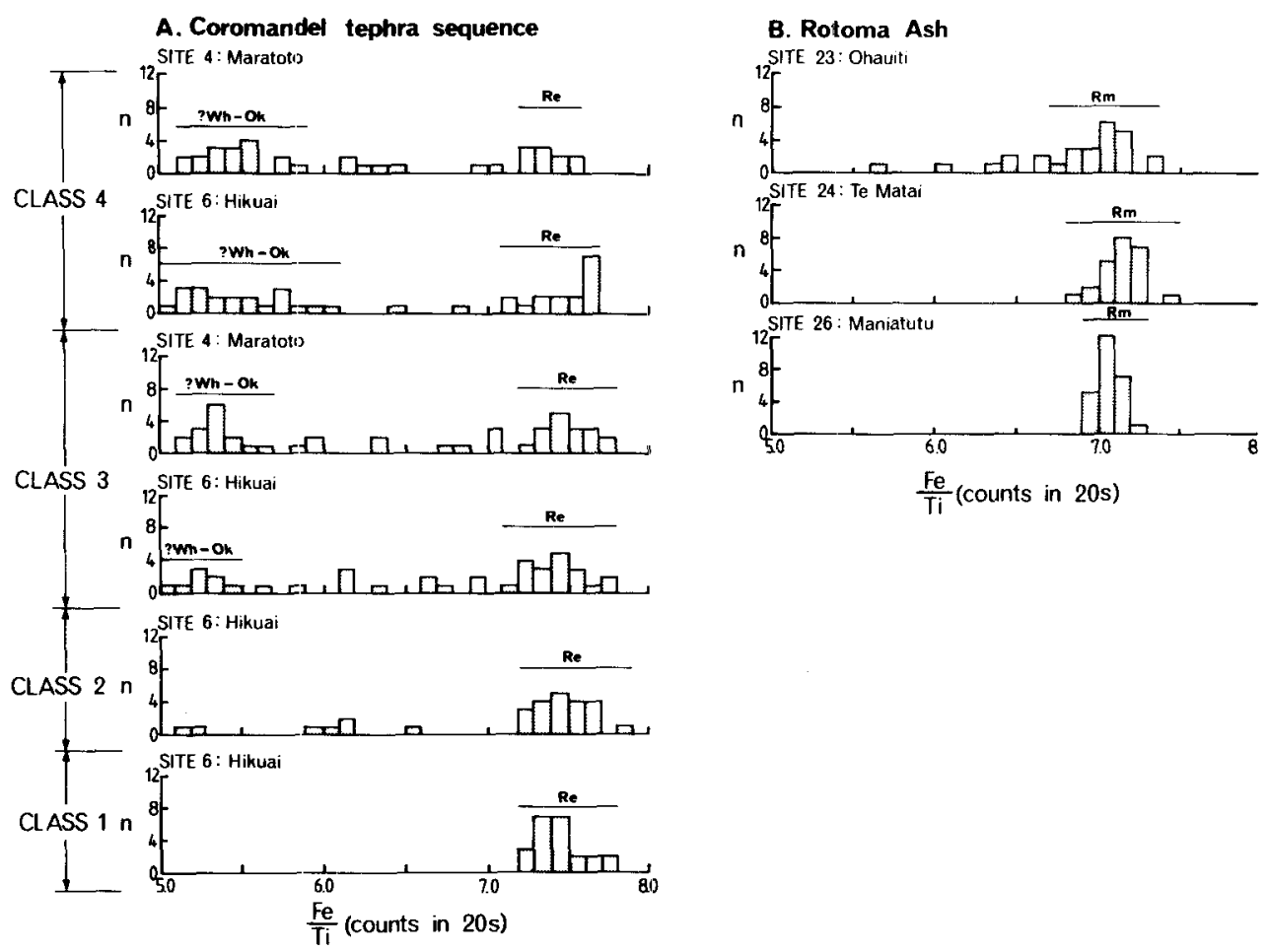

Fig. 7 - Fe/Ti ratios of titanomagnetites extracted from calcalkaline tephra beds of Coromandel Peninsula (A), and from Rotoma Ash in western Bay of Plenty (B) (based on analysis of single grains). $\mathrm{n}$, number of titanomagnetite grains in any particular $0.1 \mathrm{Fe} / \mathrm{Ti}$ ratio-interval; dominant modes are indicated by lines overlying the data points. The graphs show that the Coromandel tephra sequence, except Class I (Rotoehı Ash), is a mixed deposit. Rotoma Ash is probably absent or represented only sparsely in the Coromandel tephra sequence. Rm, Rotoma Ash; ?Wh-Ok, the Waiohau, Rotorua, Okareka tephras; Re, Rotoehu Ash (from Hogg and McCraw, 1983, p. 173).

1988a; Froggatt and Lowe, 1990). Many of these dates were assayed at New Zealand's second radiocarbon dating laboratory, established in 1975 at the University of Waikato, Hamilton (Hogg et al., 1987). The effects of different chemical pretreatments on samples for radiocarbon dating were examined by, for example, Bailey et al. (1975), Goh and Pullar (1977), and Hammond et al. (1988).

\section{Tephra fingerprinting and correlation with distal deposits}

Difficulties in tephra correlation came to light early in Period 4, especially in distal regions where the tephra deposits were known to be composite (e.g. Pullar, 1967a; Pullar and Birrell, 1973a). In these distal environments many of the diagnostic field properties are lost and laboratory methods made difficult by postdepositional mixing and weathering processes. Hodder and Wilson (1976) and Hodder (1978) made an important contribution to the study of such mixed tephra assemblages. They suggested ways of circumventing problems associated with multiple tephra populations, and showed how such populations may effectively be separated using single particle methods (e.g. very precise measurements of refractive indices of glass shards).

Later, Hogg and McCraw's (1983) study on mixed calcalkaline and peralkaline tephras of the Coromandel Peninsula, based partly on electron microprobe analyses, demonstrated some of the advantages of single particle (grain discrete) methods over multi-particle methods 
Table 3 - Characteristic dominant ferromagnesian silicate mineral assemblages* of silicic tephra deposits erupted from Taupo, Okataina, Maroa, and Tuhua [Mayor Island] volcanic centres (VC) since c. 50,000 years BP (after Froggatt and Lowe, 1990).

\begin{tabular}{|c|c|c|c|c|}
\hline $\begin{array}{l}\text { Assemblage } 1 \\
\text { Hyp } \pm \text { aug } \pm \text { hbl }\end{array}$ & $\begin{array}{l}\text { Assemblage } 2 \\
\text { Hyp }+ \text { hbl } \pm \text { aug }\end{array}$ & $\begin{array}{l}\text { Assemblage } 3 \\
\text { Hyp }+ \text { hbl }+ \text { bio }\end{array}$ & $\begin{array}{l}\text { Assemblage } 4 \\
\text { Hyp }+ \text { cgt } \pm \mathrm{hbl}\end{array}$ & $\begin{array}{l}\text { Assemblage } 5 \text { Assemblage } 6 \\
\text { Hyp }+ \text { aug } \pm \text { hbl Aegirine }\end{array}$ \\
\hline $\begin{array}{l}\text { Taupo VC } \\
\text { Taupo (all } \\
\text { members) } \\
\text { Mapara } \\
\text { Whakaipo } \\
\text { Waimihia (both } \\
\text { members) } \\
\text { Hinemaiaia } \\
\text { Motutere } \\
\text { Opepe } \\
\text { Poronui } \\
\text { Karapiti }\end{array}$ & $\begin{array}{l}\text { Okataina VC } \\
\text { Mamaku } \\
\text { Waiohau } \\
\text { Rotorua (lower } \\
\text { part) } \\
\text { Te Rere } \\
\text { Omataroa } \\
\text { Awakeri } \\
\text { Mangaone } \\
\text { Tahuna } \\
\text { Ngamotu } \\
\text { Taupo VC } \\
\text { Kawakawa } \\
\text { (both members) } \\
\text { Poihipi } \\
\text { Okaia } \\
\text { Tihoi } \\
\text { Waihora } \\
\text { Otake }\end{array}$ & $\begin{array}{l}\text { Okataina VC } \\
\text { Kaharoa } \\
\text { Rotorua (top } \\
\text { part) } \\
\text { Rerewhakaaitu } \\
\text { Okareka } \\
\text { Earthquake Flat } \\
\text { Rotoiti (top } \\
\text { part) }\end{array}$ & $\begin{array}{l}\text { Okataina VC } \\
\text { Whakatane } \\
\text { Rotoma } \\
\text { Rotoiti (except } \\
\text { Matahi mb.) }\end{array}$ & $\begin{array}{ll}\text { Okataina VC } & \text { TuhuaVC } \\
\text { Hauparu } & \text { Tuhua } \\
\text { Te Mahoe } & \\
\text { Maketu } & \end{array}$ \\
\hline
\end{tabular}

* Hyp, hypersthene; aug, augite; hbl, calcic hornblende; bio, biotite; cgt, cummingtonite

(Fig. 7). However, the study also exemplified the effort and detail that may be required to identify thinly bedded tephra deposits where the number of eruptive components is effectively unknown. Lowe $(1988 \mathrm{a}, \mathrm{b})$ showed that a more comprehensive and reliable record of tephra deposition may be obtained using sites, where available, that are more amenable to the preservation of such tephra beds (e.g. lakes or bogs).

From this and other work it became increasingly evident that unequivocal correlations of tephra using laboratory techniques commonly require multiple criteria, including: (1) stratigraphic control; (2) analysis of diagnostic and persistent tephra properties, particularly ferromagnesian silicate mineral assemblages and the chemical composition of Fe-Ti oxide, glass, or ferromagnesian mineral phases; and (3) radiometric age control if available (Lowe, 1988a; Froggatt and Lowe, 1990). An example of multiple criteria used for correlation is given in Lowe (1988a, table 3, p. 139).

Ferromagnesian mineral assemblages. The observations of Ewart and Kohn regarding ferromagnesian mineral assemblages in Period 3 were modified and extended. At present, six ferromagnesian silicate mineral assemblages are recognised for late Quaternary (post-c. 50,000 year BP) silicic tephras erupted from Taupo, Okataina, Maroa, and Tuhua [Mayor Island] volcanic centres (Table 3). The ferromagnesian mineralogy of some of the post-c. 20,000 year BP tephras from Tongariro and Mt Egmont was reported in Lowe (1987, 1988a, b).

$\mathrm{Fe}$-Ti oxides. Analyses of titanomagnetites for confirming long distance tephra correlation continued in the 1970s (Pullar et al., 1977; Kohn and Glasby, 1978; Kohn, 1979), but was essentially based on earlier data of Kohn (1973). The first new work published on Fe-Ti oxides was by Hogg and McCraw (1983), as described above. Since then, Franks (1984), 


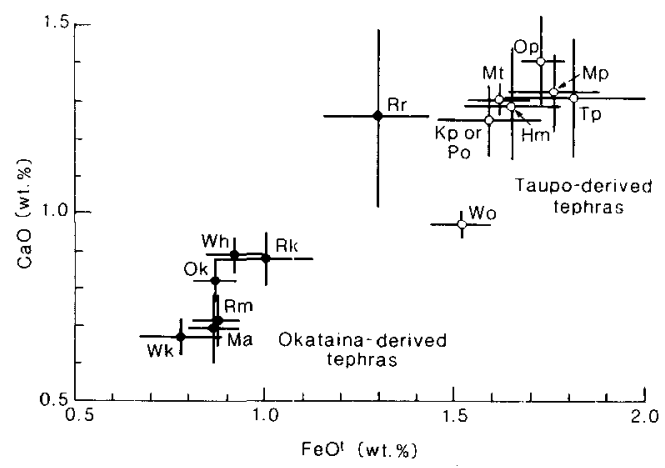

Fig. 8 - $\mathrm{CaO}$ vs FeO (total iron) in glass in tephra deposits derived from the Taupo (open circles) or Okataina (closed circles) volcanic centres. Bars are \pm 1 std. dev. of mean values. Tephra formations and number of shards analysed per tephra are: Tp Taupo (10), Mp Mapara (9), Wo Whakaipo (11), Hm Hinemaiaia (33), Mt Motutere (9), Op Opepe (7), Kp Karapiti, Po Poronui (5), Wk Whakatane (20), Ma Mamaku (14), Rm Rotoma (10), Wh Waiohau (10), Rr Rotorua (17), Rk Rerewhakaaitu (10), Ok Okareka (10) (after Lowe, 1988b, p. 118).

Froggatt and Solloway (1986), and Lowe (1988a, b) have used Fe-Ti oxide analyses in a limited way to aid tephra correlation.

Volcanic glass. Howorth and Rankin (1975) provided the only published studies on volcanic glass analyses for correlation purposes until the work of P. C. Froggatt in 1983 (Froggatt 1983; see also Froggatt and Gosson, 1982). Froggatt was the first systematically to document the basis of electron microprobe analysis of major elements of glass shards for aiding the identification of tephras and ignimbrites in New Zealand (the technique was pioneered overseas by Smith and Westgate, 1969). Subsequent tephra correlation studies using glass analyses have demonstrated the efficacy of the electron probe for this work, particularly for distal locations (Fig. 8; Green and Lowe, 1985; Nelson et al., 1985a; Froggatt and Solloway, 1986; Froggatt et al., 1986; Lowe, 1986a, 1988a, b; Eden and Froggatt, 1988). Tephra studies using trace element or rare earth element analyses of glass are uncommon (Froggatt et al., 1986; Mew et al., 1986).

Stokes and Lowe (1988) used discriminant function analysis to demonstrate the validity of tephra correlation using major element analyses of glass, and presented the first numerical classification of tephra deposits for six volcanoes in New Zealand (Fig. 9).

Composition of ferromagnesian minerals. Froggatt and Solloway (1986) and Lowe (1988a, b) used electron microprobe analyses of pyroxenes for tephra characterisation and as an adjunct for correlation. Lowe (1988a,b) suggested that some Egmont- and Tongariro-derived tephras might be separable through $\mathrm{Ca}_{2} \mathrm{Si}_{2} \mathrm{O}_{6}$ (wo) and $\mathrm{FeSiO}_{3}$ (fs) levels in clinopyroxenes.

The stratigraphy and chronology of named late Quaternary (post-50,000 years BP) silicic tephra formations from the Okataina, Taupo, Maroa, and Tuhua volcanic centres as known at present (Froggatt and Lowe, 1990) are summarised in Fig. 10. Further work on the stratigraphy and chronology of late Quaternary tephra deposits associated with the Egmont, Tongariro and Tuhua volcanic centres is in progress.

With the increasing availability of extended dating techniques (e.g. fission track analysis; amino acid racemisation) and of faster and more accurate analytical methods, more attention was given to older tephra deposits, both on land and in marine cores, and their significance for patterns of volcanism in time and space considered together with their use as tephrochronological markers (Milne, 1973; Seward, 1974, 1975, 1976, 1979; Pain, 1975; Watkins and Huang, 1977; Vucetich et al., 1978, 1981; Naeser et al., 1980; Pillans and Kohn, 1981; Vucetich et al., 1981; Froggatt, 1983; Kyle and Seward, 1984; Nelson et al., 1985a, b; Iso et al., 1982; Froggatt et al., 1986; Kennedy, 1988; Nelson, 1988; Pillans, 1988; Briggs et al., 1989; Nelson et al., 1989).

\section{Tephrochronology}

Wide-ranging tephrochronological applications are recorded for this period, particularly on tectonic and earth deformation studies (Froggatt and Howorth, 1980; Naeser et al., 1980; Pullar, 1981; Pillans, 1983; Berryman and Hull, 1984; Hull, 1986; Ota et al., 1983, 1989; Beanland et al., 1989; de Lange and Lowe, 1990), geomorphology (Pain, 1976; Kennedy et 

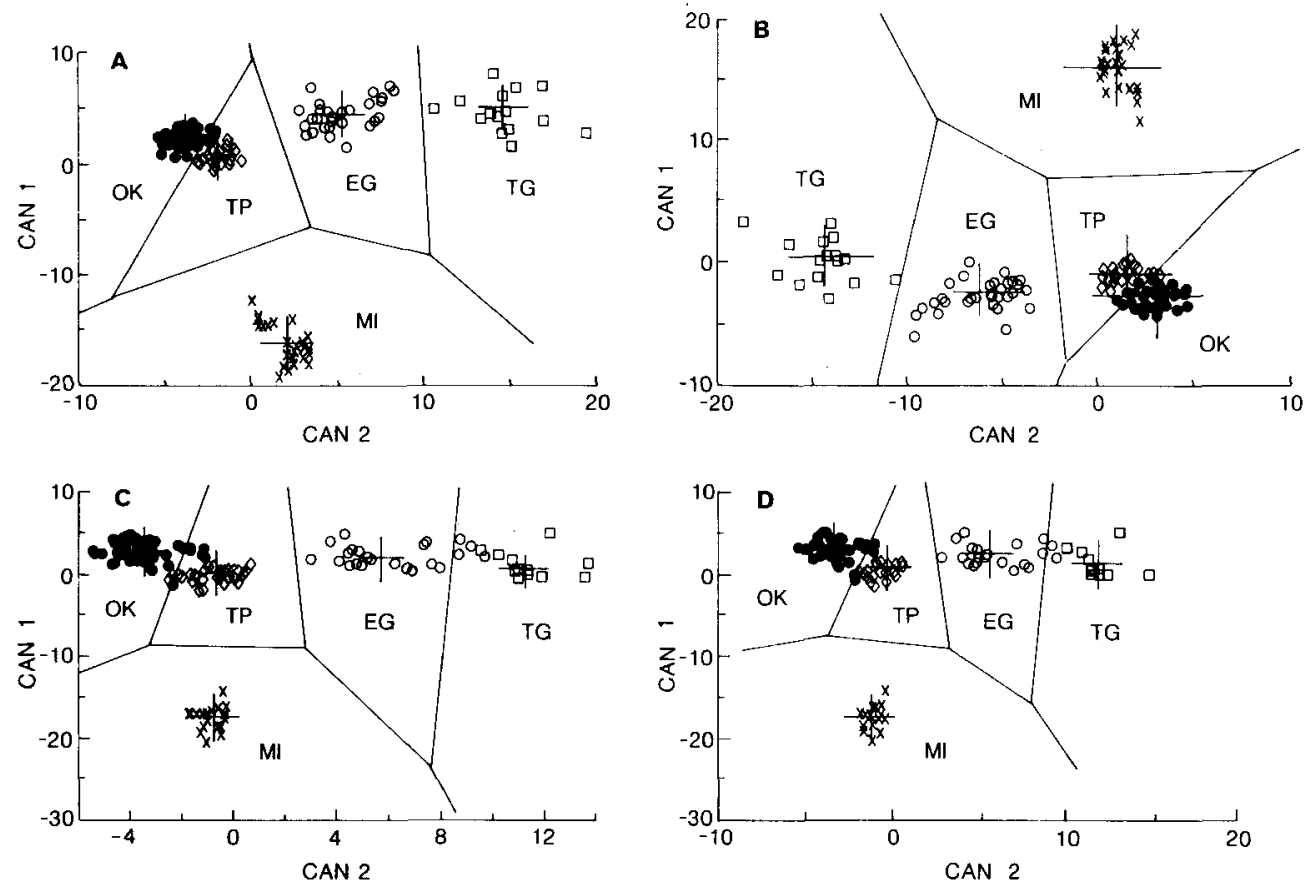

Fig. 9 - First and second canonical variates, determined by discriminant function analysis, of electronmicroprobe determined major element analyses of glass in tephra deposits from five North Island volcanic centres (EG, Egmont; MI, Mayor Island; OK, Okataina; TG, Tongariro; TP, Taupo). Four data sets are plotted: (A) raw; (B) normalised; (C) transformed $\log _{10}$ (oxide/Cl); (D) transformed $\log _{10}$ (oxide/Cl) minus outliers. Group centroids and field boundaries separating the groups are also plotted. The first two canonical discriminant functions account for $>90 \%$ of the variation between groups. FeO, $\mathrm{SiO}_{2}, \mathrm{MgO}$, and $\mathrm{K}_{2} \mathrm{O}$ were consistently selected as highly discriminating variables; $\mathrm{CaO}, \mathrm{Al}_{2} \mathrm{O}_{3}$, and $\mathrm{TiO}_{2}$ were also additionally important discriminants within specific analyses (from Stokes and Lowe, 1988, p. 277).

al., 1978; Pillans et al., 1982; Grant, 1985; Green and Lowe, 1985; Lowe and Green, 1987; Yoshikawa et al., 1988), archaeology (McFadgen, 1981, 1985; McGlone, 1983b), palaeoecology and palaeoclimate (Neall, 1975; McGlone, 1978, 1981, 1983a; McGlone and Topping, 1977, 1983; McGlone et al., 1984, 1988; Stewart and Neall, 1984; Harper et al., 1986; Newnham et al., 1989), loess correlation (Eden and Furkert, 1988), and in studies of the parent materials and rates of weathering of tephra-derived soils and paleosols (Kirkman 1975, 1976, 1980; Birrell et al., 1977, 1981; Neall, 1977; Kirkman and Pullar, 1978; Parfitt et al., 1983; Stevens and Vucetich, 1985; Lowe, 1986b, Hodder et al., in press).

\section{Advances in physical volcanology and petrology from pyroclastic deposits}

Perhaps the most significant development in tephra research since about 1980 has been its increased application to the field of physical volcanology. A similar trend is evident overseas (e.g. Self and Sparks, 1981; Fisher and Schmincke, 1984: Carey and Sparks, 1986). In New Zealand, many new studies, chiefly on the rhyolitic pyroclastics of the central TVZ, have examined the nature of the eruptions, and their effects, rather than concentrating on the stratigraphy of the deposits (e.g. Nairn and Self, 1978; Self and Sparks, 1978; Kohn and Topping, 1978; Nairn, 1980; Froggatt, 1982; Self, 1983; Wilson et al., 1984; Froggatt et al., 1986; Wilson et al., 1986; Houghton and Wilson, 1986, 1989). Many of the subsequent advances may be attributed in large part to the influence of G. P. L. Walker, a Captain James Cook Research Fellow of the Royal Society of New Zealand at the University of Auckland 


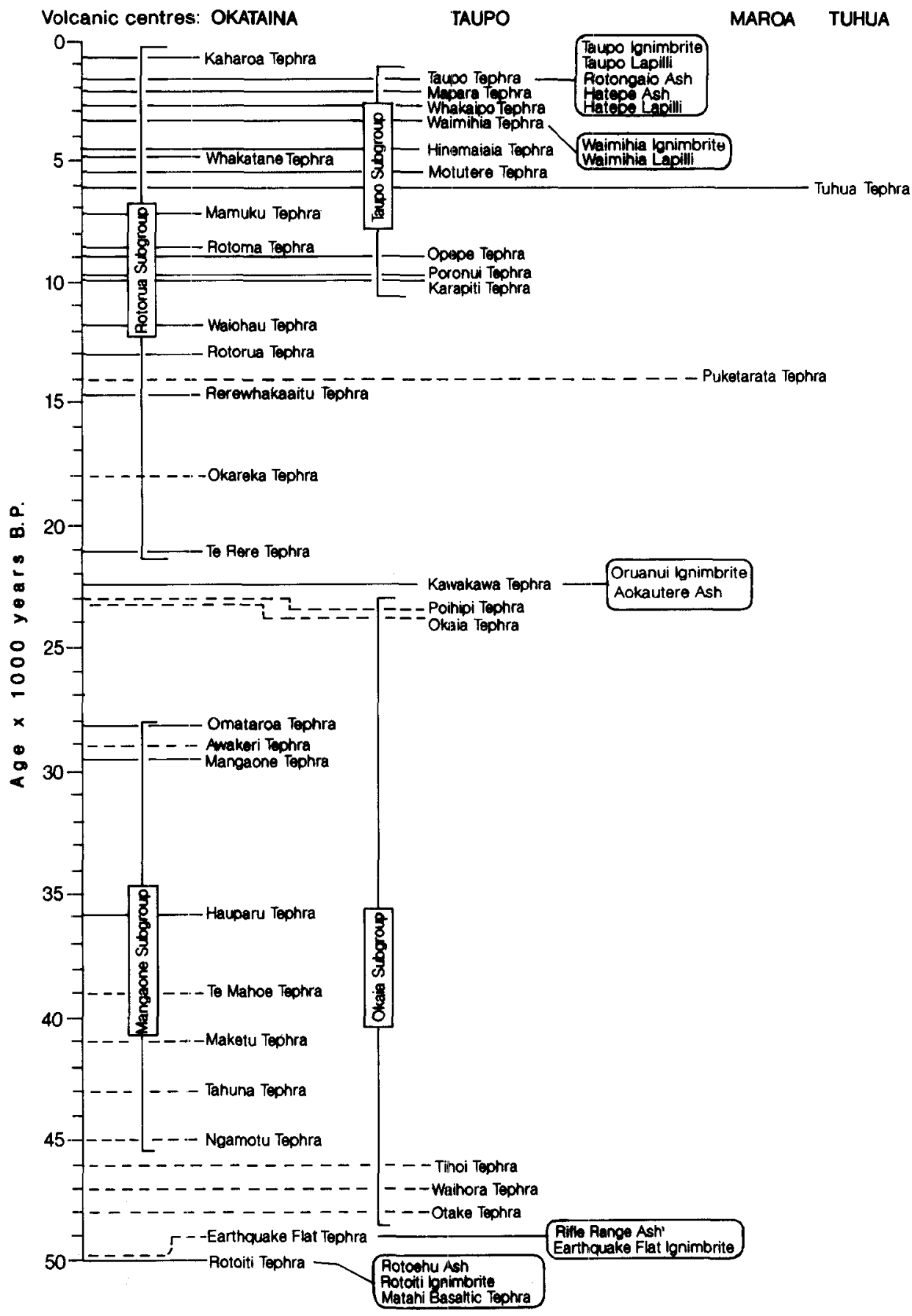

Fig. 10 - Stratigraphic and chronologic relationships of named tephra formations on mainland North Island erupted from Okataina, Taupo, Maroa, and Tuhua [Mayor Island] volcanic centres since $c$. 50,000 years BP (after Froggatt and Lowe, 1990). Named members are given in horizontal boxes. Subgroup status is shown in vertical boxes. Dashed lines indicate that age is approximate $\left({ }^{14} \mathrm{C}\right.$ dates unavailable or unreliable). N.B.: Earthquake Flat Tephra, although ascribed to the Okataina Volcanic Centre, may have derived from the Kapenga Volcanic Centre. 


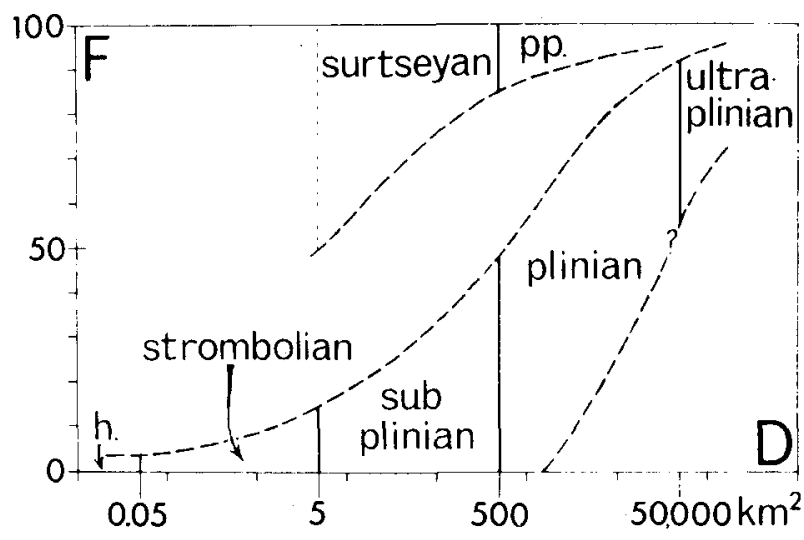

Fig. 11 - Classification of tephra fall deposits from plot of fragmentation index $F$ (=wt.\% finer than $1 \mathrm{~mm}$ where the isopach for $0.1 T_{\text {max }}$ crosses dispersal axis) against dispersal index $D$ (= area enclosed by the isopach for $0.01 T_{\max }$ ). $T_{\max }$ is the maximum thickness. The ultraplinian class is derived from analysis of Taupo Tephra eruptives. h, hawaiian; pp, phreatoplinian. (From Walker, 1980, p. 90.) from 1978-1981. Walker's dynamism, wide international experience, and simple yet highly effective approach resulted in many advances, including: (1) new methods for locating the source vent of fall deposits (not necessarily where the deposits are thickest); (2) use of crystal contents to determine the volumes of plinian deposits; (3) the distinction between magnitude, dispersive power, intensity, and violence of explosive eruptions, and the establishment of the 'ultraplinian' eruptive class (Fig. 11); (4) recognition of features of waterscavenged ashes and evidence for water being erupted with the ash and causing fluvial erosion; (5) documentation of special features

of low-aspect ratio ignimbrites; ignimbrite facies concepts; origin of co-ignimbrite ashes; (6) correlating the form of a volcano with the intensity of its eruptions (concept of inverse volcanoes) (e.g. Walker 1979, 1980, 1981a, b, c, d, e; Walker et al., 1984; Wilson et al., 1986). Walker's seminal work with C. J. N. Wilson on the Taupo eruption of c. $1850 \pm 10$ years BP (Froggatt and Lowe, 1990) is an outstanding contribution to these advances (Wilson, 1985; Wilson and Walker, 1985; Cas and Wright, 1987).

In addition, the silicic pyroclastic deposits are providing new insights in the field of volcanic petrology (e.g. Hodder, 1981; Walker, 1981a; Blake et al., 1986; Wallace et al., 1986; Dunbar et al., 1989). Such pumice deposits have great value for petrological studies (M. Storey, pers. comm., 1986): (1) a large volume pyroclastic eryption provides a rapidly quenched sample (typically inverted; Fig. 12) of a silicic magma body at a single instant in its crystallisation history (in some cases the inital magma geochemistry may be 'scrambled' by the eruption process); (2) the evidence for magma zonation or heterogeneity (e.g. magma mixing) is found primarily in glassy tephra deposits (e.g. Federman and Scheidegger, 1984; Wolff, 1985; Carr and Walker, 1987; Dunbar et al., 1989), whereas the consolidation of lava obscures the evidence; (3) pyroclastic deposits may greatly predominate volumetrically over lavas of similar major element composition for a specific volcanic centre; (4) a suite of lavas and pyroclastics may have similar major element compositions but not necessarily similar trace element abundances.

A focus for much of the volcanological and tephrostratigraphic work in the 1980s was provided by the 1986 International Volcanological Congress held in New Zealand to mark the centenary of the Tarawera eruption (Smith, 1986).

Volcanic hazards and predictions. Another major stimulus for physical volcanology that dramatically renewed the public awareness of volcanic hazards (repeating the event of 80 years earlier with Mt Pelée) was the eruption of Mt St Helens in May, 1980, and, to a lesser extent, of El Chicon in 1982 and Nevado del Ruiz in 1985. The intensive study of the products, mechanisms, and effects of these and other eruptions (e.g. Lipman and Mullineaux, 1981; Blong, 1984) rubbed off in New Zealand, and ultimately resulted in the first publications of comprehensive volcanic hazard assessments, and suggestions for mitigation (Neall, 1982; Dibble and Neall, 1984; Buck, 1985; Gregory and Watters, 1986; Latter, 1987; Houghton et al., 1987, 1988). Froggatt (1982) used estimates of erupted volumes of tephra from the 
(a)

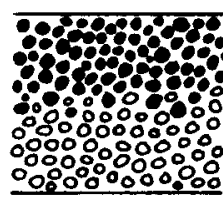

(b)

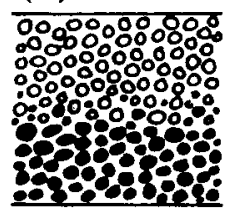

(c)

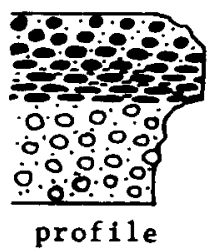

more

mafic

more

sa1ic
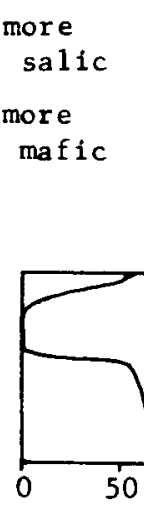
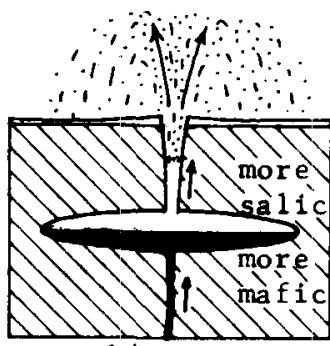

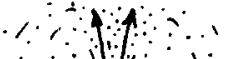
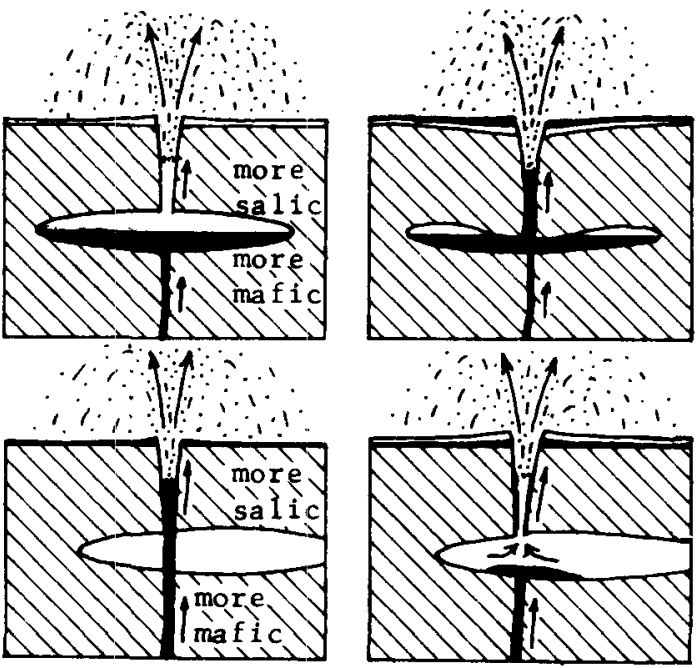

more

mafic (basaltic andesite)

more

salic (rhyolite)

Fig. 12 - Two kinds of compositionally-zoned tephra fall deposits $(a, b)$, with diagrams showing how they could have formed. Such pyroclastic deposits derive from a compositionally-zoned magma chamber, and the stratigraphic sequence in the deposit is the reverse of that in the chamber: the firsterupted fraction comes from the top of the chamber, and the last-erupted fraction comes from deepest down (after Walker, 1981a, p. 397).

Okataina and Taupo volcanoes to suggest that future eruptions might be expected in less than 400 years from Okataina and in about 8000 years from Taupo (Fig. 13).

Interest in the possible effects of explosive volcanic eruptions on climate has been renewed in New Zealand (e.g. Self et al., 1981; Kelly and Sear, 1984; Froggatt et al., 1986; Wilson et al., 1988).

\section{Status of tephra studies by the end of Period 4}

Thus, Period 4 is characterised by more specialised studies, which have built on and refined the stratigraphic framework established previously (see also Editorial in Howorth $e t$ al., 1981, and Froggatt and Lowe, 1990). Some of these stratigraphic studies have been located in areas relatively near to the tephra source volcanoes but, increasingly, other studies were aimed at identifying distal tephras and using them for dating and correlating both terrestrial and marine deposits. The stratigraphic and chronologic relationships and distribution of late Quaternary tephra deposits, particularly those erupted from central TVZ and the Tuhua Volcanic Centre, have been significantly advanced. However, perhaps the most dramatic advances in the 1980 s were those resulting from intensive studies aimed at determining the nature of the large rhyolitic eruptions. These studies have been effectively revolutionary and, together with the attainment of a more comprehensive history of volcanism through the tephrochronostratigraphic studies, should ultimately be of benefit in assessing future volcanic behaviour and its effects.

Most tephra fingerprinting methods have progressed relatively slowly, but recent work using the electron microprobe in particular has established the basis necessary for further development. Until recently, detailed fingerprinting studies involving chemical analyses of 

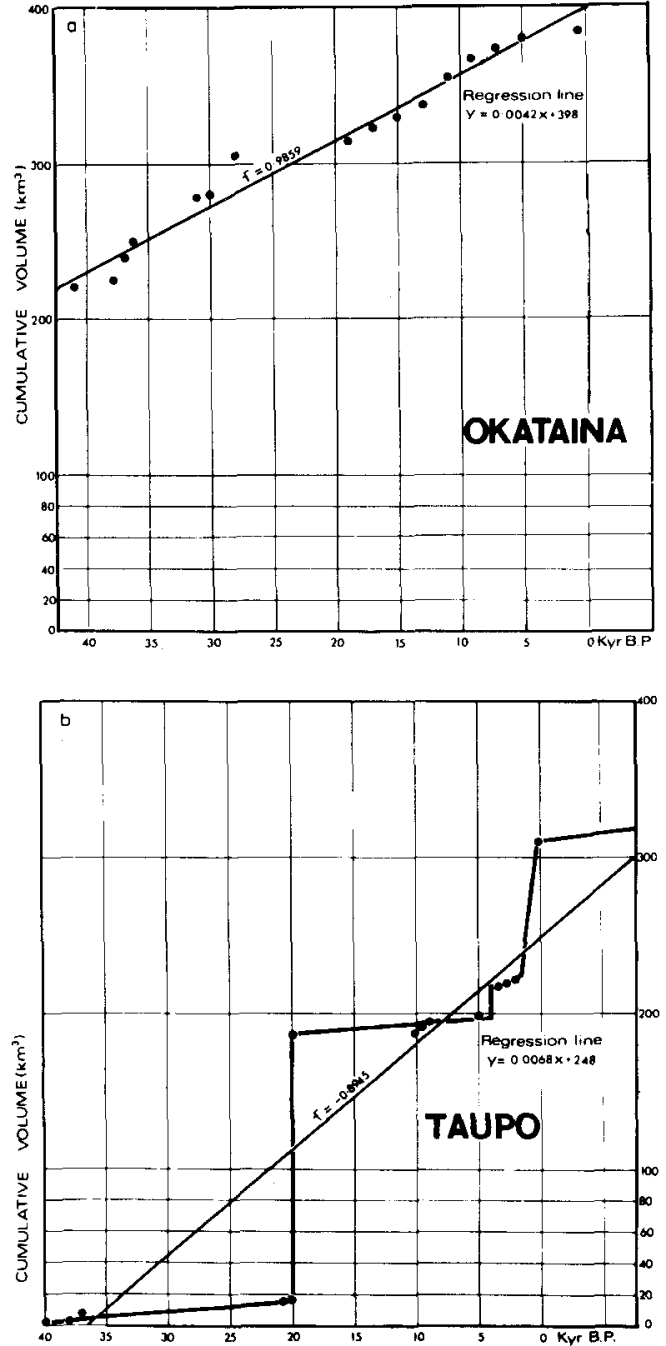

Fig. 13 - Cumulative volume plotted against age for tephras erupted from (a) Okataina, and (b) Taupo volcanic centres. Equations and correlation coefficients are for least-squares regression lines using all data; in (b) the near-horizontal steps are regression lines through relevant points only (from Froggatt, 1982, p. 314). Kyr, 1000 years BP. glass and various minerals in tephra beds in New Zealand have, in general, not matched the rapid rate of development and application in overseas countries (c.f. Smith and Westgate, 1969; Izett et al., 1972; SarnaWojcicki, 1976; Westgate and Gorton, 1981; King et al., 1982; Smith and Leeman, 1982). This relates in part to the relatively small number of people working on tephra deposits in New Zealand, but a more important influence has perhaps been the limited availability of analytical facilities in New Zealand. Generally, fundamental mineralogical and chemical data for many tephra deposits, particularly those derived from andesitic sources (e.g. Wallace et al., 1986; Stewart and Wallace, 1988), are sparse.

Late Quaternary airfall tephras have been used extensively as time stratigraphic markers in a wide range of projects; older tephras are being used increasingly in this and other roles as reliable ages are obtained for them. Studies on tephra weathering and clay mineral formation and transformations are also important areas of research, particularly in pedology and palaeopedology.

Coming of age of tephra studies. Although the INQUA Congress of 1973 represents a pinnacle of achievement for tephra studies in New Zealand, it might be argued that tephrostratigraphy and tephrochronology "came of age" as full disciplines in their own right at around the start of the 1980s. A workshop devoted solely to tephra studies was held at Victoria University of Wellington in 1980, the first such conference of its kind in New Zealand (Smalley, 1980; Howorth et al., 1981). In the same year, the first international conference on tephras was held at Reykjavik, Iceland (Self and Sparks, 1981). Since then, the major advances in physical volcanology

in New Zealand (and overseas) have been based mainly on studies of silicic fallout tephra and unwelded ignimbrite deposits (e.g. Walker, 1981a). The tremendous growth of knowledge in this area in particular is reflected in the publication of comprehensive textbooks by Fisher and Schminke (1984) and Cas and Wright (1987).

\section{CONCLUSIONS}

The development of tephra studies into a dynamic research tool in New Zealand has been influenced by various factors or events in New Zealand and overseas, including:

(1) New Zealand's volcanological (tectonic) character and relatively small land area; 
(2) the eruptions of Mt Tarawera (1886) and Mt Pelée (1902);

(3) the linking of bush sickness with the distribution of particular tephra deposits;

(4) large plantings of exotic forests in the central volcanic region;

(5) the advent of ${ }^{14} \mathrm{C}$ dating;

(6) 'secret correlation' work by pedologists on the regolith, not just the solum;

(7) development of fast and accurate analytical techniques;

(8) increased opportunities for postgraduate university education;

(9) improved communications among scientists, with experience and techniques from overseas becoming increasingly available;

(10) eruption of Mt St Helens (1980).

An additional factor might be described as the 'individualistic' factor - many advances were the result of single-minded efforts by a handful of innovative and individualistic scientists.

Major advances in tephra studies were made in the 1930s (first tephra mapping in central North Island), in the 1950 s (first use of ${ }^{14} \mathrm{C}$ dating) and 1960 s (establishment of a late Quaternary tephrostratigraphic framework by hand-over-hand mapping in central North Island and Taranaki; initial development of tephra fingerprinting using laboratory methods; applications of tephrochronology), and in the 1970s and 1980s (revision and refinement of near-source stratigraphy; extension of tephra correlation and mapping to distal regions, on and offshore, and to older deposits; advances in tephra correlation and dating methods; new applications of tephrochronology; the innovative use of pyroclastic deposits to determine the nature and effects of explosive eruptions, and their petrogenesis; renewed awareness of volcanic hazards associated with tephra eruptions). Each of these advances was made possible by, and built on, the wisdom and publications of previous generations.

The scientific discipline of 'tephra studies', called "tephrology" by Froggatt and Lowe (1990), may be regarded as having "come of age" early in the 1980s, about 100 years after the first tephrostratigraphic studies in New Zealand. It is perhaps appropriate to conclude with some comments by Jaggar (1920) about explosive volcanism in New Zealand (p.163):

"The live lava-column is always there, ready to burst forth and devastate the land, highly charged with explosive gas. The dwellers of Rotorua, Tauranga, Whakatane, and Ohakune live over it, and in some sense Wanganui, Te Kuiti, New Plymouth, Napier, Gisborne, and even Auckland are within the belt that confines the sleeping monster."

Then, referring to the more active volcanoes within the TVZ, Jagger pointed out that:

..."these places are rare treasures of nature's building - shafts many miles deep ready dug in this corner of the globe, and ready to yield priceless information when once they are harnessed for the benefit of science and humanity."

\section{ACKNOWLEDGEMENTS}

I appreciate very much the encouragement $I$ have received over many years from Emeritus Professor J. D. McCraw and Mr C. G. Vucetich, and for their helpful insights and comments regarding this paper. I also thank Drs M. Gage, P. J. Grant, J. D. G. Milne and $M$. Storey for comments or assistance with the paper.

\section{REFERENCES}

Alloway, B. V., Neall, V. E., and Vucetich, C. G., 1988. Localised volcanic loess deposits in North Taranaki, North Island, New Zealand. In D. N. Eden and R. J. Furkert (Eds): Loess. Its Distribution, Geology and Soils. pp. 1-6. A.A. Balkema, Rotterdam.

Aston, B. C., 1926. A reconnaisance survey of pumice soils. Rotorua County. IV. N.Z. Journal of Agriculture 32: 365-374.

1927. A reconnaissance survey of pumice soils. Rotorua County. V. N.Z. Journal of Agriculture 35: $96-100$. 
Bailey, J. M., Lee, R., Rankin, P. C., and Speir, T. W., 1975. Humic-acid contamination of charcoals from Quaternary tephra deposits in New Zealand. In R. P. Suggate and M. M. Cresswell (Eds): Quaternary Studies, pp. 53-55. Royal Society of N. Z., Bulletin 13.

Baumgart, I. L., 1954. Some ash showers of the central North Island. N.Z. Journal of Science and Technology B35: 456-467.

Baumgart, I. L., and Healy, J., 1956. Recent volcanicity at Taupo, New Zealand. Proceedings of the 8th Pacific Science Congress 2: 113-127.

Beanland, S., Berryman, K. R., and Blick, G. H., 1989. Geological investigations of the 1987 Edgecumbe earthquake, New Zealand. N.Z. Journal of Geology and Geophysics 32: 73-91.

Berry, J. A., 1928. The volcanic deposits of Scinde Island. With special reference to the pumice bodies called chalazoidites. Transactions of the N.Z. Institute 59: 571-608.

Berryman, K. R., and Hull, A. G., 1984. Guidebook to the North Island scientific excursions. International Symposium on Recent Crustal Movements of the Pacific region, Wellington, New Zealand. Royal Society of New Zealand, Miscellaneous Publication 8.

Birrell, K. S., and Fieldes, M., 1952. Allophane in volcanic ash soils. Journal of Soil Science 3: 156166.

- 1968. Amorphous constituents. In Soils of New Zealand, pp. 39-49. N.Z. Soil Bureau, Bulletin 26(3).

Birrell, K. S., and Pullar, W. A., 1973. Weathering of paleosols in Holocene and late Pleistocene tephras in central North Island, New Zealand. N.Z. Journal of Geology and Geophysics 16: 687-702.

Birrell, K. S., Pullar, W. A., and Searle, P. L., 1977. Weathering of Rotoehu Ash in the Bay of Plenty district. N.Z. Journal of Science 20: 303-310.

Birrell, K. S., Stevens, K. F., and Vucetich, C. G., 1981. Late Quaternary sections containing tephra and loess in the Te Kuiti district, New Zealand. In R. Howorth et al. (Eds): Proceedings of Tephra Workshop, pp. 5-10. Geology Department, Victoria University of Wellington, Publication 20.

Blake, S., Smith, I. E. M., and Wilson, C. J. N., 1986. The Waimihia pumice: insights on magma mixing and dynamics at Taupo, New Zealand. In Abstracts, p. 3. International Volcanological Congress, Auckland-Hamilton-Rotorua.

Blong, R. J., 1984. Volcanic Hazards. Academic Press, North Ryde.

Borchardt, G. A., Harward, M. E., and Schmitt, R. A., 1971. Correlation of volcanic ash deposits by activation analysis of glass separates. Quaternary Research 1: 247-260.

Briggs, R.M., Itaya, T., Lowe, D.J., and Keane, A.J., 1989. Ages of the Pliocene-Pleistocene Alexandra and Ngatutura Volcanics, western North Island, New Zealand, and some geological implications. N.Z. Journal of Geology and Geophysics 32: 417-427.

Brothers, R. N., and Golson, J., 1959. Geological and archaeological interpretation of a section in Rangitoto ash on Motutapu Island, Auckland. N.Z. Journal of Geology and Geophysics 2: 569-577.

Buck, M. D., 1985. An assessment of voleanic risk on and from Mayor Island, New Zealand. N.Z. Journal of Geology and Geophysics 28: 283-298.

Buck, M. D., Briggs, R. M., and Nelson, C. S., 1981. Pyroclastic deposits and volcanic history of Mayor Island. N.Z. Journal of Geology and Geophysics 24: 449-467.

Campbell, I. B., 1979. Occurrence of Kawakawa Tephra near Nelson. N.Z. Journal of Science 22: 133136.

1986. New occurrences and distribution of Kawakawa Tephra in South Island, New Zealand. N.Z. Jounnal of Geology and Geophysics 29: 425-435.

Carey, S., and Sparks, R. S. J., 1986. Quantitative models of the fallout and dispersal of tephra from volcanic eruption columns. Bulletin of Volcanology 48: 109-125.

Carr, M. J., and Walker, J. A., 1987. Intra-eruption changes in composition of some mafic to intermediate tephras in Central America. Joumal of Volcanology and Geothermal Research 33: 147-159.

Cas, R. A. F.. and Wright, J. V., 1987. Volcanic Successions. Allen \& Unwin, London.

Cole, J. W., 1970. Description and correlation of Holocene volcanic formations in the TaraweraRerewhakaaitu region. Transactions of the Royal Society of N.Z. (Earth Sciences) 8: 93-108.

Cole, J. W., 1986. Distribution and tectonic setting of late Cenozoic volcanism in New Zealand. In I.E.M. Smith (Ed): Late Cenozoic Volcanism in New Zealand, pp. 7-20. Royal Society of N.Z., Bulletin 23.

Cole, J. W., and Nairn, I. A., 1975. Catalogue of the active volcanoes and solfatara fields of New Zealand. International Association of Volcanology and Chemistry of the Earth's Interior. Part XXII. 
Cole, J.W., and Stephenson, T. M., 1972. Calculation of the volume of a tephra deposit. In J.W. Cole: Distribution of high alumina basalts in the Taupo Volcanic Zone, pp. 13-15. Geology Department, Victoria University of Wellington Publication, 1.

Cowie, J. D., 1964. Aokautere Ash in the Manawatu district, New Zealand. N.Z. Journal of Geology and Geophysics 7: 67-77.

Crawford, J. C., 1876. On the old lake system of New Zealand, with some observations as to the formation of the Canterbury Plains. Transactions of the N.Z. Institute (1875) 8: 369-375.

Cussen, L., 1888. Notes on the physiography and geology of the King Country. Transactions of the N.Z. Institute (1887) 20: 316-332.

de Lange, P.J., and Lowe, D.J., 1990. History of vertical displacement of Kerepehi Fault at Kopouatai bog, Hauraki Lowlands, New Zealand, since c. 10700 years ago. N.Z. Journal of Geology and Geophysic's 33 (in press).

Dibble, R. R., and Neall, V. E., 1984. Voleanic hazards in New Zealand. In I. Speden and M.J. Crozier (compilers): Natural Hazards in New Zealand, pp. 332-374. N.Z. National Commission for UNESCO, Wellington.

Druce, A. P., 1966. Tree-ring dating of recent volcanic ash and lapilli, Mt Egmont. N.Z. Journal of Botany 4: 3-41.

Dunbar, N. W., Kyle, P. R., and Wilson, C. J. N., 1989. Evidence for limited zonation in silicic magma systems, Taupo Volcanic Zone, New Zealand. Geology 17: 234-236.

Duncan, A. R., 1970. The petrology and petrochemistry of andesite and dacite volcanoes in eastern Bay of Plenty, New Zealand. Unpublished Phd Thesis, Victoria University of Wellington.

Duncan, A. R., and Taylor, S. R., 1968. Trace element analyses of magnetites from andesitic and dacitic lavas from Bay of Plenty, New Zealand. Lithos 3: 30-33.

Eden, D. N., 1987. Stratigraphy and chronology of Seaview Formation, Awatere Valley, South Island, New Zealand. In Liu Tungsheng (Ed): Aspects of Loess Research, pp. 216-230. China Ocean Press, Beijing.

Eden, D. N., and Furkert, R. J. (Eds), 1988. Loess. Its Distribution, Geology and Soils. A.A. Balkema, Rotterdam.

Eden, D. N., and Froggatt, P. C., 1988. Identification and stratigraphic significance of distal Aokautere Ash in three loess cores from eastern South Island, New Zealand. $\ln$ D. N. Eden and R. J. Furkert (Eds): Loess. Its Distribution, Geology and Soils, pp. 47-58. A.A. Balkema, Rotterdam.

Ewart, A., 1963. Petrology and petrogenesis of the Quaternary pumice ash in the Taupo area, New Zealand. Journal of Petrology 4: 392-431.

1966. Review of mineralogy and chemistry of the acidic volcanic rocks of Taupo Volcanic Zone New Zealand. Bulletin Volcanologique 29: 147-172.

1968. The petrology of the central North Island rhyolitic lavas. Part 2. Regional petrography including notes on associated ash-flow pumice deposits. N.Z. Journal of Geology and Geophysics 11: 478-545.

-1971. Notes on the chemistry of ferromagnesian phenocrysts from selected volcanic rocks, central volcanic region. N.Z. Journal of Geology and Geophysics 14: 323-340.

Federman, A. N., and Carey, S. N., 1980. Electron microprobe correlation of tephra layers from eastern Mediterranean abyssal sediments and the island of Santorini. Quaternary Research 13: 160-171.

Federman, A. N., and Scheidegger, K. F., 1984. Compositional heterogeneity of distal tephra deposits from the 1912 eruption of Novarupta, Alaska. Journal of Volcanology and Geothermal Research 21 : 233-254.

Fergusson, G. J., and Rafter, T. A., 1953. New Zealand 14C age measurements - 1. N.Z. Journal of Science and Technology B35: 127-128.

Fisher, R. V., and Schmincke, H.-U., 1984. Pyroclastic Rocks. Springer Verlag, Berlin-Heidelberg.

Franks, A. M., 1984. Soils of Eltham County and the tephrochronology of central Taranaki. Unpublished PhD Thesis, Massey University.

Froggatt, P. C., 1979. Lake Taupo - probable source of Taupo Pumice Formation. N.Z. Journal of Geology and Geophysics 22: 763-764.

1981a. Stratigraphy and nature of Taupo Pumice Formation. N.Z. Journal of Geology and Geophysics 24: 231-248.

_ 1981b. Motutere Tephra Formation and redefinition of Hinemaiaia Tephra Formation, Taupo Volcanic Centre, New Zealand. N.Z. Journal of Geology and Geophysics 24: 99-105.

1981c. Karapiti Tephra Formation: a 10000 years B.P. rhyolitic tephra from Taupo. N.Z. Journal of Geology and Geophysics 24: 95-98 
1982. Review of methods of estimating rhyolitic tephra volumes; applications to the Taupo Volcanic Zone, New Zealand. Journal of Volcanology and Geothermal Research 14:301-318.

- 1983. Toward a comprehensive Upper Quaternary tephra and ignimbrite stratigraphy in New Zealand using electron microprobe analysis of glass shards. Quaternary Research 19: 188-200.

Froggatt, P. C., and Gosson, G. J., 1982. Techniques for the preparation of tephra samples for mineral and chemical analysis and radiometric dating. Geology Department, Victoria University of Wellington. Publication 23.

Froggatt, P. C., and Howorth, R., 1980. Uniformity of vertical faulting for the last 7000 years at Lake Poukawa, Hawke's Bay, New Zealand. N.Z. Journal of Geology and Geophysics 23: 493-497.

Froggatt, P. C., and Lowe, D. J., 1990. A review of late Quaternary silicic and some other tephra formations from New Zealand: their stratigraphy, nomenclature, distribution, volume, and age. N.Z. Journal of Geology and Geophysics 33 (in press).

Froggatt, P. C., and Solloway, G. J., 1986. Correlation of Papanetu Tephra to Karapiti Tephra, central North Island, New Zealand. N.Z. Journal of Geology and Geophysics 29: 303-313.

Froggatt, P. C., Nelson, C. S., Carter, L., Griggs, G., and Black, K.P., 1986. An exceptionally large late Quaternary eruption from New Zealand. Nature 319: 578-582.

Geddes, A. M., and Neall, V. E., 1982. Elucidation of the Stratford Shower, Taranaki. In V. E. Neall (Ed): Soil Groups of New' Zealand. Part 6. Yellow-brown loams, pp. 16-22. N.Z. Society of Soil Science, Wellington.

Geddes, A. M., Neall, V. E., and Stewart, R. B., 1981. Recent discovery of the westernmost occurrences of Aokautere Ash and implications for the late Quaternary in Taranaki. In R. Howorth et al. (Eds): Proceedings of Tephra Workshop, pp. 29-32. Geology Department, Victoria University of Wellington, Publication 20.

Gibbs, H. S., 1968. Volcanic-ash soils in New Zealand. N.Z. Department of Scientific and Industrial Research Information Series 65.

Goh, K. M., and Pullar, W. A., 1977. Radiocarbon dating techniques for tephras in central North Island, New Zealand. Geoderma 18: 265-278.

Grange, L. I., 1929. A classification of soils of Rotorua County. N.Z. Journal of Science and Technology 11:219-228.

1931. Volcanic ash showers. N.Z. Journal of Science and Technology 12: 228-240.

1937. The geology of the Rotorua-Taupo Subdivision. N.Z. Geological Survey Bulletin 37.

Grange, L. I., and Taylor, N. H., 1932. The distribution and field characteristics of bush-sick soils. Part 2A. In Bush Sickness, pp. 21-35. N.Z. Department of Scientific and Industrial Research, Bulletin 32.

Grange, L. I., Taylor, N. H., Sutherland, C. F., Dixon, J. K., Hodgson, L., Seelye, F. T., Kidson, E., Cranwell, L. M., and Smallfield, P. W., 1939. Soils and agriculture of part of Waipa County. N.Z. Department of Scientific and Industrial Research. Bulletin 76.

Grant, P. J., 1985. Major periods of erosion and alluvial sedimentation in New Zealand during the Late Holocene. Journal of the Royal Society of N.Z. 15: 67-121.

Gregory, J. G., and Watters, W. A. (Eds), 1986. Volcanic hazards assessment in New Zealand. N.Z. Geological Survey, Record 10.

Green, J. D., and Lowe, D. J., 1985. Stratigraphy and development of c. 17000 year old Lake Maratoto, North Island, New Zealand. with some inferences about postglacial climatic change. N.Z. Journal of Geology and Geophysics 28: 675-699.

Hammond, A. P., Tonkin, P. J., and Manning, M. R., 1988. Interpretation of radiocarbon dates with respect to a tephra age control in a gley podzol and associated peats: Graham's Terrace, north Westland. In R. Lee (Collator): Proceedings, N.Z. Society of Soil Science Conference, Nelson, pp. 22-23. N.Z. Society of Soil Science, Lower Hutt.

Harper, M. A., Howorth, R., and McLeod, M., 1986. Late Holocene diatoms in Lake Poukawa: effects of airfall tephra and changes in depth. N.Z. Joumal of Marine and Freshwater Research 20: 107118.

Healy, J., 1964. Stratigraphy and chronology of late Quaternary volcanic ash in Taupo, Rotorua, and Gisborne districts. Part 1. Dating of the younger volcanic eruptions of the Taupo region. N.Z. Geological Survey Bulletin 73: 7-42.

- 1982. Central volcanic region. In J. M. Soons and M. J. Selby (Eds): Landforms of New' Zealand, pp. 161-192. Longman Paul, Auckland.

Hill, H., 1887. Traces of volcanic dust-showers at Napier, Petane, and generally throughout the East Coast districts, north of Cape Kidnappers. Transactions of the N.Z. Institute (1886) 19: 385-387. 
1888. Pumice: its geological distribution on the East Coast of the North Island of New Zealand, extending from Tolaga Bay to Cape Turnagain. Transactions of the N.Z. Institute (1887) 20: 293306.

Hodder, A. P. W., 1978. Refractive index and hydration of rhyolitic glass from Holocene tephras, North Island, New Zealand. N.Z. Journal of Geology and Geophysics 21: 155-166.

1981. Titanomagnetites in tephras: some implications from crystal field theory. Chemical Geology 32: 102-118.

Hodder, A.P.W., Green, B.E., and Lowe, D.J., in press. A two-stage model for the formation of clay minerals from volcanic glass. Clay Minerals.

Hodder, A. P. W., and Wilson, A. T., 1976. Identification and correlation of thinly bedded tephra: the Tirau and Mairoa Ashes. N.Z. Journal of Geology and Geophysics 19: 663-682.

Hogg, A. G., 1979. Identification and correlation of thinly bedded late Quaternary tephras of Coromandel Peninsula, New Zealand. Unpublished DPhil thesis, University of Waikato.

Hogg, A. G., and McCraw, J. D., 1983. Late Quaternary tephras of Coromandel Peninsula, North Island, New Zealand: a mixed peralkaline and calcalkaline tephra sequence. N.Z. Journal of Geology and Geophysics 26: 163-187.

Hogg, A. G., Lowe, D. J., and Hendy, C. H., 1987. University of Waikato radiocarbon dates I. Radiocarbon 29: 263-301.

Houghton, B. F., and Wilson, C. J. N., 1986. Explosive rhyolitic volcanism: the case studies of Mayor Island and Taupo volcanoes. In B. F. Houghton and S. D. Weaver (Eds): North Island Volcanism, pp.33-100. N.Z. Geological Survey, Record 12.

462.

Houghton, B. F., Wilson, C. J. N., and Weaver, S. D., 1985. The Ruru Pass Tephra, a peralkaline airfall tuff from Mayor Island. N.Z. Geological Survey Record 8: 30-36.

Houghton, B. F., Latter, J. H., and Hackett, W. R.,1987. Volcanic hazard assessment for Ruapehu composite volcano, Taupo Volcanic Zone, New Zealand. Bulletin of Volcanology 49: 737-75I.

Houghton, B. F., Latter, J. H., and Froggatt, P. C., 1988. Volcanic hazard in New Zealand. Geological Society of New' Zealand Miscellaneous Publication $41 D$.

Howorth, R., 1975. New formations of late Pleistocene tephras from the Okataina Volcanic Centre, New Zealand. N.Z. Journal of Geology and Geophysics 18: 683-712.

Howorth, R., and Rankin, P. C., 1975. Multi-element characterisation of glass shards from stratigraphically correlated rhyolitic tephra units. Chemical Geology 15: 239-250.

Howorth, R. and Ross, A., 1981. Holocene tephrostratigraphy and chronology ant Tiniroto, Cook County. In R. Howorth et al. (Eds): Proceedings of Tephra Workshop, pp. 41-50. Geology Department, Victoria University of Wellington, Publication 20.

Howorth, R., and Topping, W. W., 1979. Rhyolitic late Pleistocene tephras to the south and west of Lake Taupo, New Zealand. N.Z. Journal of Geology and Geophysics 22: 759-762.

Howorth, R., Froggatt, P. C., and Robertson, S. M., 1980. Late Quaternary volcanic ash stratigraphy of the Poukawa area, central Hawke's Bay, New Zealand. N.Z. Iournal of Geology and Geophysics 23: 487-491.

Howorth, R., Froggatt, P. C., Vucetich, C. G., Collen, J. D. (Eds), 1981. Proceedings of Tephra Workshop. June 30th-July 1st. 1980, Victoria University of Wellington. Geology Department, Victoria University of Wellington, Publication 20.

Hull, A. G., 1986. Pre-A.D. 1931 tectonic subsidence of Ahuriri Lagoon, Napier, Hawke's Bay, New Zealand. N.Z. Journal of Geology and Geophysics 29: 75-82.

Iso, N., Okada, A., Ota, Y., and Yoshikawa, T., 1982. Fission-track ages of late Pleistocene tephra on the Bay of Plenty coast, North Island, New Zealand. N.Z. Journal of Geology and Geophysics 25: 295-303.

Izett, G. A., Wilcox, R. E., and Borchardt, G. A., 1972. Correlation of a volcanic ash bed in Pleistocene deposits near Mount Blanco, Texas, with the Guaje pumice bed of the Jemez Mountains, New Mexico. Quaternary Research 2: 554-578.

Jagger, T. A., 1920. A New Zealand department of volcano research. N.Z. Journal of Science and Terhnology 3: 162-167.

Kamp, P. J. J., 1986. Late Cretaceous-Cenozoic tectonic development of the southwest Pacific region. Tectonophysics 121: 225-251.

Kelly, P. M., and Sear, C. B., 1984. Climatic impact of explosive volcanic eruptions. Nature 311: 740743. 
Kennedy, N. M., 1988. Late Quaternary loess associated with the Mamaku Plateau, North Island, New Zealand.In D. N. Eden and R. J. Furkert (Eds): Loess. Its Distribution, Geology and Soils, pp. 71-80. A.A. Balkema, Rotterdam.

Kennedy, N. M., Pullar, W. A., and Pain, C. F., 1978. Late Quaternary land surfaces and geomorphic changes in the Rotorua Basin, North Island, New Zealand. N.Z. Journal of Science 21: 249-264.

King, R. H., Kingston, M. S., and Barnett, R. L., 1982. A numerical approach toward the classification of magnetites from tephra in southern Alberta. Canadian Journal of Earth Sciences 19: 2012-2019.

Kirkman, J. H., 1975. Clay mineralogy of some tephra beds of Rotorua area, North Island, New Zealand. Clay Minerals 10: 437-449.

1976. Clay mineralogy of thirteen paleosols developed in Holocene and Late Pleistocene tephras of central North Island, New Zealand. N.Z. Journal of Geology and Geophysics 19: 179-187.

1980. Clay mineralogy of a sequence of andesitic tephra beds of western Taranaki, New Zealand. Clay Minerals 15: 157-163.

Kirkman, J. H., and Pullar, W. A., 1978. Halloysite in late Pleistocene rhyolitic tephra beds near Opotiki, coastal Bay of Plenty, North Island, New Zealand. Australian Journal of Soil Research 16: $1-8$.

Kohn, B. P., 1970. Identification of New Zealand tephra-layers by emission spectrographic analysis of their titanomagnetites. Lithos 3: 361-368.

1973. Studies of New Zealand Quaternary pyroclastic rocks. Unpublished PhD Thesis, Victoria University of Wellington.

1979. Identification and significance of a late Pleistocene tephra in Canterbury district, South Island, New Zealand. Quaternary Research 11: 78-92.

Kohn, B. P., and Glasby, G. P., 1978. Tephra distribution and sedimentation rates in the Bay of Plenty, New Zealand. N.Z. Journal of Geology and Geophysics 21: 49-70.

Kohn, B.P., and Neall, V.E., 1973. Identification of late Quaternary tephras for dating Taranaki lahar deposits. N.Z. Journal of Geology and Geophysics 16: 781-792.

Kohn, B. P., and Topping, W. W., 1978. Time-space relationships between late Quaternary rhyolitic and andesitic volcanism in the southern Taupo Volcanic Zone, New Zealand. Geological Society of America Bulletin 89: 1265-1271.

Kohn, B. P., Neall, V. E., and Stewart, R. B., 1981. Holocene tephrostratigraphy revisited at Tiniroto, North Island, New Zealand. In R. Howorth et al. (Eds): Proceedings of Tephra Workshop, pp. 60-66. Geology Department, Victoria University of Wellington, Publication 20.

Kyle, P. R., and Seward, D., 1984. Dispersed rhyolitic tephra from New Zealand in deep-sea sediments of the Southern Ocean. Geology 12: 487-490.

Latter, J. H., 1987. Volcanic hazard map of Tongariro National Park region 1:100 000. N.Z. Department of Scientific and Industrial Research, Wellington.

Lewis, K. B., and Kohn, B. P., 1973. Ashes, turbidites, and rates of sedimentation on the continental slope off Hawke's Bay. N.Z. Journal of Geology and Geophysic's 16: 439-454.

Lipman, P. W., and Mullineaux, D. R. (Eds), 1981. The 1980 eruptions of Mount St. Helens, Washington. United States Geological Survey Professional Paper 1250.

Lowe, D. J., 1986a. Revision of the age and stratigraphic relationships of Hinemaiaia Tephra and Whakatane Ash, North Island, New Zealand, based on distal deposits in lake sediments and peats. N.Z. Journal of Geology and Geophysics 29: 61-73.

1986b. Controls on the rates of weathering and clay mineral genesis in airfall tephras: a review and New Zealand case study. In S.M. Colman and D.P. Dethier (Eds): Rates of Chemical Weathering of Rocks and Minerals, pp. 265-330. Academic Press, Orlando.

1987. Studies on late Quaternary tephras in the Waikato and other regions in northern North Island, New Zealand, hased on distal deposits in lake sediments and peats. Unpublished DPhil Thesis, University of Waikato.

1988a. Stratigraphy, age, composition, and correlation of late Quaternary tephras interbedded with organic sediments in Waikato lakes, North Island, New Zealand. N.Z. Journal of Geology and Geophysics 31: 125-165.

1988b. Late Quaternary volcanism in New Zealand: towards an integrated record using distal airfall tephras in lakes and bogs. Joumal of Quatemary Science 3: 111-120.

Lowe, D. J., and Green, J. D., 1987. Origins and development of the lakes. In A.B. Viner (Ed): Inland Waters of New Zealand, pp. 1-64. N.Z. Department of Scientific and Industrial Research, Bulletin 240. 
Lowe, D. J., and Hogg, A. G., 1986. Tephrostratigraphy and chronology of the Kaipo Lagoon, an 11,500 year-old montane peat bog in the Urewera National Park, New Zealand. Journal of the Royal Society of N.Z. 16:25-41.

Lowe, D. J., Hogg, A. G., Green, J. D., and Boubée, J. A. T., 1980. Stratigraphy and chronology of late Quaternary tephras in Lake Maratoto, Hamilton, New Zealand. N.Z. Journal of Geology and Geophysics 23: 481-485.

McCraw, J. D., 1975. Quaternary airfall deposits of New Zealand. In R. P. Suggate and M. M. Cresswell (Eds): Quaternary Studies, pp. 35-44. Royal Society of N. Z., Bulletin 13.

McFadgen, B. G., 1981. Tephras in archaeology. In R. Howorth ef al. (Eds): Proceedings of Tephra Workshop, pp. 78-79. Geology Department, Victoria University of Wellington, Publication 20.

1985. Late Holocene stratigraphy of coastal deposits between Auckland and Dunedin, New Zealand. Journal of the Royal Society of N.Z. 15:27-65.

McGlone, M. S., 1978. Forest destruction by early Polynesians, Lake Poukawa, Hawke's Bay, New Zealand. Journal of the Royal Society of N.Z. 8: 275-281.

- 1981. Forest fire following Holocene teplhra fall. In R. Howorth ef al. (Eds): Proceedings of Tephra Workshop, pp. 80-86. Geology Department, Victoria University of Wellington, Publication 20.

1983a. Holocene pollen diagrams, Lake Rotorua, North Island, New Zealand. Journal of the Royal Society of N.Z. 13:53-65.

-1983b. Polynesian deforestation of New Zealand: A preliminary synthesis. Archaeology in Oceania 18: 11-25.

McGlone, M. S., and Topping, W. W., 1977. Aranuian (post-glacial) pollen diagrams from the Tongariro region, North Island, New Zealand. N.Z. Journal of Botany 15: 749-760.

_ 1983. Late Quaternary vegetation, Tongariro region, central North Island, New Zealand. N.Z. Journal of Botany $21: 53-76$.

McGlone, M. S., Howorth, R., and Pullar, W. A., 1984. Late Pleistocene stratigraphy, vegetation and climate of the Bay of Plenty and Gisborne regions, New Zealand. N.Z. Journal of Geology and Geophysics 27: 327-350.

McGlone, M. S., Neall, V. E., and Clarkson, B. D., 1988. The effect of recent volcanic events and climatic changes on the vegetation of Mt Egmont (Mt Taranaki), New Zealand. N.Z. Journal of Botany 26: $123-144$.

McIntosh, P. D., Eden, D. N., Burgham, S. J., and Froggatt, P. C., 1988. Volcanic glass and terrace chronology in the Gore region, Southland. Geological Society of N.Z. Newsletter 80; 54-56.

McKay, A., 1899. Report on the pumice-stone deposits of the middle part of the North Island. Appendix to the Journal of the House of Representatives C-9: 16-25.

Mew, G., Hunt, J. L., Froggatt, P. C., Eden, D. N., and Jackson, R. J., 1986. An occurrence of Kawakawa Tephra from the Grey River valley, South Island, New Zealand. N.Z. Iounal of Geology and Geophysics 29: 315-322.

Milne, J. D. G., 1973. Mount Curl Tephra, a 230 000-year-old marker bed in New Zealand, and its implications for Quaternary chronology. N.Z. Journal of Geology and Geophysics 16: 519-532.

Milne, J. D. G., and Smalley, I. J., 1979. Loess deposits in the southern part of the North Island of New Zealand: An outline stratigraphy. Acta Geologica Academiae Scientarium Hungaricae 22: 197-204.

MOW, 1962. National Resources Survey, Part II. Bay of Plenty Region. Compiled by Town and Country Planning Branch, Ministry of Works. N.Z. Government Printer, Wellington.

Naeser, C. W., Nishimura, S., and Te Punga, M. T., 1980. Fission-track age of the Mangaroa Ash and tectonic implications at Wellington, New Zealand. N.Z. Journal of Geology and Geophysics 23: 615-620.

Nairn, I. A., 1972. Rotoehu Ash and the Rotoiti Breccia Formation, Taupo Volcanic Zone, New Zealand. N.Z. Journal of Geology and Geophysics 15: 251-261.

1980. Source, age, and eruptive mechanisms of Rotorua Ash. N.Z. Joumal of Geology and Geophysics 23: 193-207.

-1981. Some studies of the geology, volcanic history, and geothermal resources of the Okataina Volcanic Centre, Taupo Volcanic Zone. New Zealand. Unpublished PhD Thesis, Victoria University of Wellington.

Nairn, I. A., and Self, S., 1978. Explosive eruptions and pyroclastic avalanches from Ngauruhoe in February, 1975. Journal of Volcanology and Geothermal Research 3: 39-60.

Neall, V. E., 1972. Tephrochronology and tephrostratigraphy of western Taranaki (N108-N109), New Zealand. N.Z. Joumal of Geology and Geophysics 15: 507-557. 
1975. Climate-controlled tephra redeposition on Pouakai ring plain, Taranaki, New Zealand. N.Z. Journal of Geology and Geophysics 18: 317-326.

1977. Genesis and weathering of Andosols in Taranaki, New Zealand. Soil Science 123: 400408.

1982. Volcanic hazard map of Mount Egmont 1:100 000. N.Z. Depatment of Scientific and Industrial Research, Wellington.

Neall, V. E., and Alloway, B. V., 1986. Quaternary volcaniclastics and volcanic hazards of Taranaki. In B.F. Houghton and S.D. Weaver (Eds): North Island Volcanism, pp. 101-137. N.Z. Geological Survey, Record 12.

Neall, V. E., and Geddes, A. M., 1981. Elucidation of the late Quaternary tephrostratigraphy in Taranaki, New Zealand. In R. Howorth et al. (Eds): Proceedings of Tephra Workshop, pp. 89-91. Geology Department, Victoria University of Wellington, Publication 20.

Neall, V. E., Alloway, B. V., and Stewart, R. B.,1988. Taranaki volcanoes. In P. J. J. Kamp and D. J. Lowe (Compilers): Field Trip Guides, Geological Society of N.Z. Annual Conference, pp. 17-35. Geological Society of N.Z., Miscellaneous Publication 41B/C.

Nelson, C. S., 1988. Revised age of a late Quaternary tephra at DSDP Site 594 off eastern South Island and some implications for correlation. Geological Society of N.Z. Newsletter 82: 35-40.

Nelson, C. S., Froggatt, P. C., and Gosson, G. J., 1985a. Nature, chemistry, and origin of late Cenozoic megascopic tephras in Leg 90 cores from the southwest Pacific. In J. P. Kennett and C. C. von der Borch et al. (Eds): Initial Reports of Deep Sea Drilling Project 90, pp. 1161-1173. U.S. Government Printing Office, Washington.

Nelson, C. S., Briggs, R. M., and Kamp, P. J. J., 1985b. Nature and significance of volcanogenic deposits at the Eocene/Oligocene boundary, Hole 593, Challenger Plateau, Tasman Sea. In J. P. Kennett and C. C. von der Borch et al. (Eds): Initial Reports of Deep Sea Drilling Project 90, pp. 1175-1187. U.S. Government Printing Office, Washington.

Nelson, C.S., Kamp, P.J.J., and Mildenhall, D.C., 1989. Late Pliocene distal silicic ignimbrites, Port Waikato, New Zealand; implications for volcanism, tectonics, and sea-level changes in South Auckland. N.Z. Journal of Geology and Geophysics 32: 357-370.

Newnham, R. M., Lowe, D. J,, and Green, J. D., 1989. Palynology, vegetation, and climate of the Waikato lowlands, North Island, New Zealand, since c. 18,000 years ago. Journal of the Royal Society of N.Z. 19: 127-150.

Ninkovich, D., 1968. Pleistocene volcanic eruptions in New Zealand recorded in deep-sea sediments. Earth and Planetary Science Letters 4: 89-102.

N.Z. Soil Bureau, 1954. General survey of the soils of North Island, New Zealand. N.Z. Soil Bureau, Bulletin 5.

Oliver, W. R. B., 1931. An ancient Maori oven on Mount Egmont. Joumal of the Polynesian Society 40: 73-80.

Ota, Y., Yoshikawa, T., Iso, N., Ikeda, Y., Moriya, I., and Hull, A. G., 1983. Holocene marine terraces in the northeastern coast of North Island, New Zealand. In Abstracts, pp. 109-112. International Symposium on Coastal Evolution in the Holocene, Tokyo.

Ota, Y., Omura, A., and Iwata, H., 1989. ${ }^{231 / \mathrm{Th}}-{ }^{2 \times 8} \mathrm{U}$ age of Rotoehu Ash and its implications for marine terrace chronology of eastern Bay of Plenty, New Zealand. N.Z. Iournal of Geology and Geophysics 32: 327-331.

Pain, C. F., 1975. Some tephra deposits in the southwest Waikato area, North Island, New Zealand. N.Z. Journal of Geology and Geophysics 18: 541-550.

1976. Late Quaternary dune sands and associated deposits near Aotea and Kawhia Harbours, North Island, New Zealand. N.Z. Journal of Geology and Geophysics 19: 153-177.

Pain, C. F., and Pullar, W. A., 1968. Chronology of fans and terraces in the Galatea Basin. Earth Science Journal 2: 1-14.

Palmer, A. S., 1982. Kawakawa Tephra in Wairarapa, New Zealand, and its use for correlating Ohakea loess. N.Z. Journal of Geology and Geophysics 25: 305-315.

Parfitt, R. L., Russell, M., and Orbell, G. E., 1983. Weathering sequence of soils from volcanic ash involving allophane and halloysite, New Zealand. Geoderma 29: 4I-57.

Pillans, B. J., 1983. Upper Quaternary marine terrace chronology and deformation, south Taranaki, New Zealand. Geology 11: 292-297.

Pillans, B. J., 1988. Loess chronology in Wanganui Basin, New Zealand. In D. N. Eden and R. J. Furkert (Eds): Loess. Its Distribution, Geology and Soils, pp. 175-192. A.A. Balkema, Rotterdam. 
Pillans, B. J., and Kohn, B. P., 1981. Rangitawa Pumice: a widespread(?) Quaternary marker bed in Taranaki-Wanganui. In R. Howorth et al. (Eds): Proceedings of Tephra Workshop, pp. 94-104. Geology Department, Victoria University of Wellington, Publication 20.

Pillans, B. J., Pullar, W. A., Selby, M. J., and Soons, J. M., 1982. The age and development of the New Zealand landscape. In J. M. Soons and M. J. Selby (Eds): Landforms of New Zealand, pp. 15-43. Longman Paul, Auckland.

Pullar, W. A., 1967a. Volcanic ash beds in the Waikato district. Earth Science Journal 1: 17-30. 1967b. Uses of volcanic ash beds in geomorphology. Earth Science Journal 1: 164-177. 1970. Pumice ash beds and peaty deposits of archaeological significance near Lake Poukawa, Hawke's Bay. N.Z. Journal of Science 13: 687-705.

-1973 . Tephra marker beds in the soil and their application in related sciences. Geoderma 10: $161-168$.

1981. Recent earth movements in Whakatane Graben suggested by tephra markers and surficial deposits. In R. Howorth et al. (Eds): Proceedings of Tephra Workshop, pp. 110-113. Geology Department, Victoria University of Wellington, Publication 20.

Pullar, W. A., and Birrell, K. S., 1973a. Parent materials of Tirau silt loam. N.Z. Journal of Geology and Geophysics 16: 677-686.

$-1973 \mathrm{~b}$. Age and distribution of late Quaternary pyroclastic and associated cover deposits of the Rotorua and Taupo area, North Island, New Zealand. N.Z. Soil Survey, Report 1.

Pullar, W. A., and Heine, J. C., 1971. Ages, inferred from ${ }^{14} \mathrm{C}$ dates, of some tephra and other deposits from Rotorua, Taupo, Bay of Plenty, Gisborne and Hawke's Bay districts. Proceedings of Radiocarhon Users' Conference, Wellington: 118-138.

Pullar, W.A., and McLean, I., 1966. Tephrachronology in the Bay of Plenty region. N.Z. Science Review 24: 36-38.

Pullar, W. A., and Nairn, I. A., 1972. Matahi Basaltic Tephra Member, Rotoiti Breccia Formation. N.Z. Journal of Geology and Geophysics 15: 446-450.

Pullar, W. A., and Penhale, H. R., 1970. Periods of recent infilling of the Gisborne Plains basin associated marker beds and changes in shoreline. N.Z. Journal of Science 13:410-434.

Pullar, W. A., and Selby, M. J., 1971. Coastal progradation of Rangitaiki Plains, New Zealand. N.Z. Journal of Science 14: 419-434.

Pullar, W. A., and Warren, W. G., 1968. Regression trend lines of ridges and swales on the emergent beach at Gisborne, New Zealand. Earth Science Journal 2: 145-159.

Pullar, W. A., Birrell, K. S., and Heine, J. C., 1973. Named tephras and tephra formations occurring in the central North Island, with notes on derived soils and buried paleosols. N.Z. Journal of Geology and Geophysics 16: 497-518.

Pullar, W. A., Kohn, B. P., and Cox, J. E., 1977. Air-fall Kaharoa Ash and Taupo Pumice, and searafted Loisels Pumice, Taupo Pumice, and Leigh Pumice in northern and eastern parts of the North Island, New Zealand. N.Z. Journal of Geology and Geophysics 20: 697-717.

Rankin, P. C., 1973. Correlation of volcanic glasses in tephras and soils using micro-element compositions. N.Z. Journal of Geology and Geophysics 16: 637-641.

Rhea, K. P., 1968. Aokautere Ash, loess, and river terraces in the Dannevirke district, New Zealand. N.Z. Journal of Geology and Geophysics 11: 685-692.

Robertson, S. M., and Mew, G., 1982. The presence of volcanic glass in soils of the West Coast, South Island, New Zealand. N.Z. Journal of Geology and Geophysics 25: 503-507.

Sarna-Wojcicki, A. M., 1976. Correlation of late Cenozoic tuffs in the central Coast Ranges of California by means of trace- and minor-element chemistry. United States Geological Survey Professional Paper 972.

Selby, M. J., Pullar, W. A., and McCraw, J. D., 1971. The age of Quaternary surfaces at Waihi Beach. Earth Science Journal 5: 106-113.

Self, S., 1983. Large-scale phreatomagmatic silicic volcanism: a case study from New Zealand. Journal of Volcanology and Geothermal Research 17: 433-469.

Self, S., and Sparks, R. S. J. (Eds), 1981. Tephra Studies. D. Reidel, Dordrecht.

Self, S., Rampino, M. R., and Barbera, J. J., 1981. The possible effects of large 19th and 20th century volcanic eruptions on zonal and hemispheric surface temperatures. Journal of Volcanology and Geothermal Research 11: 41-60.

Seward, D., 1974. Age of New Zealand Pleistocene substages by fission-track dating of glass shards from tephra horizons. Earth and Planetary Science Letters 24: 242-248. 
1975. Fission-track ages of some tephras from Cape Kidnappers, Hawke's Bay, New Zealand. N.Z. Journal of Geology and Geophysics 18: 507-510.

_ 1976. Tephrostratigraphy of the marine sediments in the Wanganui Basin, New Zealand. N.Z. Journal of Geology and Geophysic's 19: 9-20. 482.

Smalley, I., 1980. Volcanic ash southern style. Nature 286: 841.

Smith, I. E. M. (Ed), 1986. Late Cenozoic Volcanism in New Zealand. Royal Society of N.Z., Bulletin 23.

Smith, S. P., 1877. Sketch of the geology of the northern portion of the Hawke Bay. Transactions of the N.Z. Institute (1876) 9: 565-576.

Smith, D. R., and Leeman, W. P., 1982. Mineralogy and phase chemistry of Mount St. Helens sets W and $\mathrm{Y}$ as keys to their identification. Quaternary Research 17: 211-227.

Smith, D. G. W., and Westgate, J. A., 1969. Electron probe technique for characterising pyroclastic deposits. Earth and Planetary Science Letters 5: 313-319.

Stevens, K. F., and Vucetich, C. G., 1985. Weathering of Upper Quaternary tephras in New Zealand, 2. Clay minerals and their climatic interpretation. Chemical Geology 53: 237-247.

Stewart, R. B., and Neall, V. E., 1984. Chronology of palaeoclimatic change at the end of the last glaciation. Nature 311: 47-48.

Stewart, R. B., and Wallace, R. C., 1988. A comparison of mineral assemblages from tephras and lavas erupted from Egmont volcano, Taranaki. In P. J. J. Kamp (Compiler): Programme and Absracts, Geological Society of N.Z. Annual Conference, p. 149. Geological Society of N.Z., Miscellaneous Publication $41 \mathrm{~A}$.

Stewart, R. B., Neall, V. E., Pollok, J. A., and Syers, J. K., 1977. Parent material stratigraphy of an Egmont loam profile, Taranaki, New Zealand. Australian Journal of Soil Research 15: 177-190.

Stokes, S., and Lowe, D. J., 1988. Discriminant function analysis of late Quaternary tephras from five volcanoes in New Zealand using glass shard major element chemistry. Quaternary Research 30: 270-283.

Suggate, R. P., Stevens, G. R., and Te Punga, M. T. (Eds), 1978. The Geology of New Zealand. N.Z. Government Printer, Wellington.

Taylor, N. H., 1930. The relation of geology to sheep sickness in Mairoa district. N.Z. Journal of Science and Technology 12:1-10.

-1933. Soil processes in volcanic ash-beds. N.Z. Journal of Science and Technology 14: 193 202, 338-352.

-1953. The ecological significance of the central North Island ash showers - the soil pattern. Proceedings of the N.Z. Ecological Society 1: 11-12.

Te Punga, M. T., 1963. An ash bed near Upper Hutt, Wellington. N.Z. Journal of Geology and Geophysics 6: 155-159.

Thomas, A. P. W., 1888. Report on the Eruption of Tarawera and Rotomahana. N.Z. Government Printer, Wellington.

- 1889. Notes on the geology of Tongariro and the Taupo district. Transactions of the N.Z. Institute (1888) 21: 338-353.

Thorarinsson, S., 1981. Tephra studies and tephrochronology: a historical review with special reference to Iceland. In S. Self and R. S. J. Sparks (Eds): Tephra Studies, pp. 1-12. D. Reidel, Dordrecht.

Tonkin, P. J., 1970. Contorted stratification with clay lobes in volcanic ash beds, Raglan-Hamilton region, New Zealand. Earth Science Journal 4: 129-140.

Topping, W. W., 1972. The Burrell Lapilli eruptions, Mt. Egmont, New Zealand. N.Z. Journal of Geology and Geophysics 15: 476-490.

-1973. Tephrostratigraphy and chronology of late Quaternary eruptives from the Tongariro Volcanic Centre, New Zealand. N.Z. Journal of Geology and Geophysic's 16: 397-423.

Topping, W.W., and Kohn, B. P., 1973. Rhyolitic tephra marker beds in the Tongariro area, North Island, New Zealand. N.Z. Journal of Geology and Geophysics 16: 375-395.

von Hochstetter, F., 1864. The Geology of New Zealand (Translated by C. A. Fleming, 1959). N.Z. Government Printer, Wellington.

Vucetich, C. G., 1968. Soil-age relationships for New Zealand based on tephro-chronology. Transactions 9th International Congress of Soil Science IV: 121-130.

_ 1977. On the retirement of Dr Alan Pullar from Soil Bureau. N.Z. Soil News 25: 222-223. 
1983. William Alexander Pullar BSc, AOSM, DSc, FNZIAS 1912-1982. Geological Society of N.Z. Newsletter 61: 62-63.

Vucetich, C. G., and Howorth, R., 1976a. Proposed definition of the Kawakawa Tephra, the c. 20000 years B.P. marker horizon in the New Zealand region. N.Z. Journal of Geology and Geophysics 19: 43-50.

1976b. Late Pleistocene tephrostratigraphy' in the Taupo district, New Zealand. N.Z. Journal of Geology and Geophysics 19: 51-69.

Vucetich, C. G., and Pullar, W. A.,1963. Ash beds and soils in the Rotorua district. Proceedings of the N.Z. Ecological Society 10: 65-72.

1964. Stratigraphy and chronology of late Quaternary volcanic ash in Taupo, Rotorua, and Gisborne districts. Part 2. Stratigraphy of Holocene ash in the Rotorua and Gisborne districts. N.Z. Geological Survey Bulletin 73: 43-78.

1969. Stratigraphy and chronology of late Pleistocene volcanic ash beds in central North Island, New Zealand. N.Z. Journal of Geology and Geophysics 12: 784-837.

1973. Holocene tephra formations erupted in the Taupo area, and interbedded tephras from other sources. N.Z. Journal of Geology and Geophysics 16: 745-780.

Vucetich, C. G., Birrell, K. S., and Pullar, W. A., 1978. Ohinewai Tephra Formation, a c. 150000 yearold tephra marker in New Zealand. N.Z. Joumal of Geology and Geophysics 21: 71-73.

Vucetich, C. G., Kohn, B. P., and Pullar, W. A., 1981. Correlation of Aratora Tephra, Ahuroa cover bed type section, Te Kuiti. In R. Howorth et al. (Eds): Proceedings of Tephra Workshop, pp. 116-I30. Geology Department, Victoria University of Wellington, Publication 20.

Walker, G. P. L., 1979. A volcanic ash generated by explosions where ignimbrite entered the sea. Nature 281: 642-646.

1980. The Taupo Pumice: product of the most powerful known (ultraplinian) eruption? Journal of Volcanology and Geothermal Research 8: 69-94.

1981a. New Zealand case histories of pyroclastic studies. In S. Self and R. S. J. Sparks (Eds): Tephra Studies, pp. 317-330. D. Reidel, Dordrecht.

1981b. The Waimihia and Hatepe plinian deposits from the rhyolitic Taupo Volcanic Centre. N.Z. Joumal of Geology and Geophysics 24: 305-324.

-1981c. Generation and dispersal of fine ash and dust by volcanic eruptions. Journal of Volcanology and Geothermal Research 11:81-92.

1981d. Characteristics of two phreatoplinian ashes, and their water-flushed origin. Journal of Volcanology and Geothermal Research 9: 395-407.

1981e. Plinian eruptions and their products. Bulletin Volcanologique 44: 223-240.

Walker, G. P. L., Self, S., and Wilson, L., 1984. Tarawera 1886, New Zealand - a basaltic plinian fissure eruption. Journal of Volcanology and Geothermal Research 21: 61-78.

Wallace, R. C., Alloway, B. V., Stewart, R. B., and Neall, V. E., 1986. Tephra mineral chemistry as an indicator of petrogenesis at Egmont volcano. In Abstracts, p. 23. International Volcanological Congress, Auckland-Hamilton-Rotorua.

Ward, W. T., 1967. Volcanic ash beds of the lower Waikato Basin, North Island, New Zealand. N.Z. Journal of Geology and Geophysics 10: 1109-1135.

Watkins, N. D., and Huang, T. C., 1977. Tephras in abyssal sediments east of North Island, New Zealand: chronology, paleowind velocity, and paleoexplosivity. N.Z. Journal of Geology and Geophysics 20: 179-199.

Wellman, H. W., 1962. Holocene of the North Island of New Zealand: a coastal reconnaissance. Transactions of the Royal Society of N.Z. (Geology) 1: 29-99.

Westgate, J. A., and Gold, C. M., 1974. World Bibliography and Index of Quaternary Tephrochronology. Printing Services Department, University of Alberta, Edmonton.

Westgate, J. A., and Gorton, M. P., 1981. Correlation techniques in tephra studies. In S. Self and R. S. J. Sparks (Eds): Tephra Studies, pp. 73-94. D. Reidel, Dordrecht.

Wilson, C. J. N., 1985. The Taupo eruption, New Zealand, II. The Taupo ignimbrite. Royal Society of London Philosophical Transactions A314: 229-310.

Wilson, C. J. N., and Walker, G. P. L.. 1985. The Taupo eruption, New Zealand, I. General aspects. Royal Society of London Philosophical Transactions A314: 199-228.

Wilson, C. J. N., Rogan, A. M., Smith, I. E. M., Northey, D. J., Nairn, I. A., Houghton, B. F., 1984. Caldera volcanoes of the Taupo Volcanic Zone, New Zealand. Journal of Geophysical Research 89(B 10): 8463-8484. 
Wilson, C. J. N., Houghton, B. F., and Lloyd, E. F., 1986. Volcanic history and evolution of the MaroaTaupo area, central North Island. In I. E. M. Smith (Ed): Late Cenozoic Volcanism in New Zealand, pp. 194-223. Royal Society of N.Z., Bulletin 23.

Wilson, C. J. N., Switsur, V. R., and Ward, A. P., 1988. A new 14C age for the Oruanui (Wairakei) eruption, New Zealand. Geological Magazine 125: 296-300.

Wolff, J. A., 1985. The effect of explosive eruption processes on geochemical patterns within pyroclastic deposits. Journal of Volcanology and Geothermal Research 26: 189-201.

Yoshikawa, T., Ikeda, Y., Iso, N., Moriya, i. Hull, A. G., and Ota, Y., 1988. Origin and age of erosion surfaces in the upper drainage basin of 'Naiapu River, northeastern North Island, New Zealand. N.Z. Journal of Geology and Geophysics 31: 101-109. 